\title{
Determinants of Bank Lending Interest Rates in Tanzania
}

\author{
Wilfred E. Mbowe*, Aristedes Mrema, Sia Shayo \\ Economic Research and Policy Directorate, Bank of Tanzania, Dar es Salaam, Tanzania \\ Email: *wembowe@bot.go.tz
}

How to cite this paper: Mbowe, W. E. Mrema, A., \& Shayo, S. (2020). Determinants of Bank Lending Interest Rates in Tanzani. American Journal of Industrial and Business Management, 10, 1206-1236. https://doi.org/10.4236/ajibm.2020.107081

Received: May 27, 2020

Accepted: July 20, 2020

Published: July 23, 2020

Copyright $\odot 2020$ by author(s) and Scientific Research Publishing Inc. This work is licensed under the Creative Commons Attribution International License (CC BY 4.0).

http://creativecommons.org/licenses/by/4.0/ (c) (i) Open Access

\begin{abstract}
The study seeks to examine the determinants of bank lending interest rates in Tanzania, largely focusing on identifying the key determinants and their relative importance. Techniques employed comprise interest rates decomposition and econometric estimation using banks' annual balance sheet data. Results on interest rates decomposition suggest that, the main drivers of lending rates are operating costs, non-performing loans; and costs of funds (deposits interest rates). The three factors accounted for 70.4 percent of small banks' average lending rates in 2014-17; while for medium and large banks, they constituted about 69.5 percent and 67.4 percent of the lending rates, respectively. Statutory minimum requirement ratio (SMR) appears to play an important role in all banks' lending rates, but its share has been declining overtime consistent with the expansionary monetary policy measures pursued since 2014 . With respect to econometric estimations, the findings confirm the role of operating costs, non-performing loans, and cost of funds in explaining bank lending rates dynamics. Operating costs, cost of funds, and inflation have a statistically significant positive effect on bank lending rates, while bank size and level of liquidity have a negative influence. SMR ratio is statistically significant but bears a negative sign except for locally owned banks. In relative importance, the main determinants of bank lending rates could be ranked as follows: inflation with an average positive impact of 0.432 on lending rates for a unit change in inflation, trailed by operating costs $(0.261)$, and cost of funds (0.255). Bank size has the largest negative effect of 0.288 for every unit increase in the variable. The implication of the findings is that effort should be directed at improving operational efficiency aiming at reducing banks operating costs. The key areas of attention are with respect to employees' salaries and benefits, as well as rental and depreciation expenses related to premises and equipment. Banks may consider to take advantage of ICT advancement in the country to cut on costs of "mortal and brick" and employees. Priority could be put on utilizing the growing agent banking framework, and digital
\end{abstract}


banking technology. Prudent consolidation of small banks could as well help cut on operating costs, improve efficiency, and enhance liquidity levels. Measures need to be taken to reduce non-performing loans including through enhancing borrowers screening mechanisms enabled by credit risk management frameworks at bank level and mandatory use of credit reference system to reduce credit risk. Strengthening of the regulatory and supervisory role is important mostly targeting to ensure adequate liquidity in the banking system for daily needs. It is recommended to cautiously reduce SMR so as to enhance banks' lending capacity.

\section{Keywords}

Lending Interest Rates, Tanzania Banking Sector, Banks Operating Costs, Lending Rates Decomposition, Econometric Estimation

\section{Introduction}

Tanzania embarked on a series of financial reforms in the 1990s with a view to supporting the development of a market-based financial sector (Bank of Tanzania $[\mathrm{BoT}], 2011)^{1}$. With the reforms, the ratio of banks credit to the private sector to gross domestic product (GDP) increased from 4.1 percent in 2001 to 16.0 percent in 2016 (Mbowe, 2018). Despite the achievement, the credit level is still far below that of comparable countries in the region. In 2017 for example, the share of credit to GDP for Kenya was 29.3 percent while those of Mozambique, Namibia, and South Africa were 25.64 percent, 63.76 percent and 147.7 percent, respectively. Compared with selected regional averages, the same situation reveals as Sub-Saharan Africa had 48.3 percent. Meanwhile, the lower middle-income group to which Tanzania has graduated and the aspired middle-income group registered 43.7 percent and 99.3 percent of GDP, respectively ${ }^{2}$. Cihak and Podpiera (2005) attribute the limited extent of lending in Tanzania to high intermediation costs including interest rate spreads, which according to Manamba (2014), are significantly higher after the adoption of financial liberalization. As discussed in Section 2, the spreads have been much elevated since 1998 contributed by lending interest rates rigidity especially from 2003 .

High interest rate spreads signal banking sector inefficiency and, when that occurs, it hampers not only financial development but also economic growth as credit to productive use is constrained due to high lending rates which are a cost to investors (Nanjunga et al., 2016). Lending interest rate to charge also matters to a commercial bank since profit banks earn-the interest income-makes a significant component of their revenues (Bhattarai, 2015; Nanjunga et al., 2016).

\footnotetext{
${ }^{1}$ King and Levine (1993a, 1993b), Demirguc-Kunt and Maksimovic (1998), and Levine and Zervos (1998) urge that well-functioning markets not only support economic development, but also enhance the effectiveness of monetary policy since they provide a mechanism for mobilization and allocation of financial resources.

${ }^{2}$ Source: https://data.worldbank.org/indicator/fs.ast.prvt.gd.zs, accessed on 23 February 2018.
} 
Profitability notwithstanding, banks are faced with another challenge: pursuit to continue relationship with borrowers; implying that high loan interest rates are less ideal for banks because they discourage borrowing by economic agents.

This study seeks to investigate determinants of bank lending interest rates in Tanzania. Specifically, it: 1) identifies factors which influence bank lending interest rates in the country, and 2) evaluates the relative importance of the factors. The findings contribute in understanding the key factors that influence banks in deciding on loan rates to charge. Such information could inform policy decisions with a view to improving efficiency in the banking sector to spur growth of credit to the private sector. Efficient credit markets are also essential in enhancing the effectiveness of the monetary policy as the country like other East African countries is set to adopt an interest rate targeting framework. The framework makes use of banks short term interest rates as key decision variables.

After the introduction, Section 2 provides a synopsis of banking sector policy and interest rates evolution in Tanzania, lagged in Sections 3 and 4 by the literature on determinants of bank lending interest rates, and methodology, respectively. Estimations and discussion of study findings follow in Section 5. Section 6 concludes the paper.

\section{Banking Sector Policy and Interest Rates Evolution in Tanzania}

\subsection{Banking Sector Policy}

Since independence in 1961, the banking sector in Tanzania has undergone profound changes in terms of growth, size and structure. In 1991 when comprehensive financial reforms and liberalization commenced, the banking sector comprised only six banks ${ }^{3}$, with lending largely directed to support socio-economic activities as per the State Credit Plans (BoT, 2016). Due to inefficiencies associated with this system including dismal growth and few financial products offered in the market, comprehensive financial sector reforms commenced in 1991, which allowed entry of private (local and foreign) commercial banks under the supervision and regulation of Bank of Tanzania (BoT). With these, interest rates were subjected to market forces. Other measures that had effect on interest rates are in respect to widening of the central bank's oversight functions to cover community banks in 2003, and deposit-taking microfinance and microcredit institutions and credit reference bureaus in 2006 (BoT, 2016). In addition, since 2007, BoT adopted a more risk-focused approach of supervising banks. A formal mechanism for sharing of credit information and reduce information asymmetry on borrowers through the establishment of a databank and private credit reference bureaus followed in 2012. The main objective was to safeguard the integrity of the banking sector while boosting its growth including credit to the private

${ }^{3}$ These were National Bank of Commerce, the People's Bank of Zanzibar, Postal Office Savings Bank, Tanzania Housing Bank, Tanzania Investment Bank, and Tanzania Rural Development Bank-the state owned banks, all being state owned banks. 
sector.

Open market operations (OMO), introduced in 1993/1994, is the main policy instrument that provides mechanism to achieve objects of: anchoring of interest rate determination, liquidity management and financing of fiscal deficits (Mbowe, 2017). The existing auction procedure gives the market more influence in determining the prices and yields, at which Treasury bills are traded.

Banks can access intraday and Lombard facilities and Repurchase agreement (REPO), which were introduced in 2003 and 2007, respectively, to square their daily or short-term liquidity needs. Other developments which may have influenced banks' lending and loan rate setting behavior are in respect to statutory requirements. The statutory minimum reserve (SMR) instrument was actively used, especially, in the second half of 1990s, to control excess liquidity in the economy. Generally, the composition of SMR and the rate have been changing over time, mainly depending on the liquidity condition in the banking system and the need to enhance financial intermediation. At end-December 2019, the SMR was 7 percent, a reduction from 10 percent in 2016 targeted at reversing the general declining trend of the contraction of credit to the private sector, exhibited from 2015. Through the discount window, started in 1994, the monetary authority may as well affect interest rates for monetary policy purposes.

The liberalization and reform efforts contributed significantly to the expansion of the banking sector in the country. At the end of 2018, the banking sector comprised 53 institutions, of which 40 were fully-fledged commercial banks, 6 community banks, 5 microfinance institutions and 2 development finance institutions. The private sector dominates, owning 48 banking institutions, while 5 are publicly owned banks. In terms of foreign and local ownership, 31 banking institutions were majority-foreign owned with about 43 percent of the banking sector assets and 22 were majority-locally owned, with 57 percent of the assets. Meanwhile, commercial banks held 94.3 percent of the total banking sector assets $^{4}$ at the end of 2018, and 68.4 percent of the total financial sector assets ${ }^{5}$ at the end of June 2017 (BoT, 2018).

Progress has also been registered in money supply, banks assets, credit to private sector, and deposits mobilization (Figures 1-3). In absolute terms or ratios, an upward trend is evident for extended broad money supply, banks assets, credit to private sector, and deposits. This is an indication of increasing financial intermediation in the country. Credit is fairly distributed across many sectors of the economy, although dominance of personal, trade and manufacturing activities cannot be denied.

The developments have implications on interest rates primarily through the interplay of supply and demand factors. Half of banks' credit was absorbed by

\footnotetext{
${ }^{4}$ Banks were followed by development financial institutions which held 3.0 percent of the banking sector assets; financial institutions (1.9 percent); microfinance institutions (0.6 percent); and community banks ( 0.3 percent).

${ }^{5}$ At the same period, pensions held 29.3 percent of the financial sector assets; insurance (1.7 percent) and collective schemes (0.6 percent).
} 


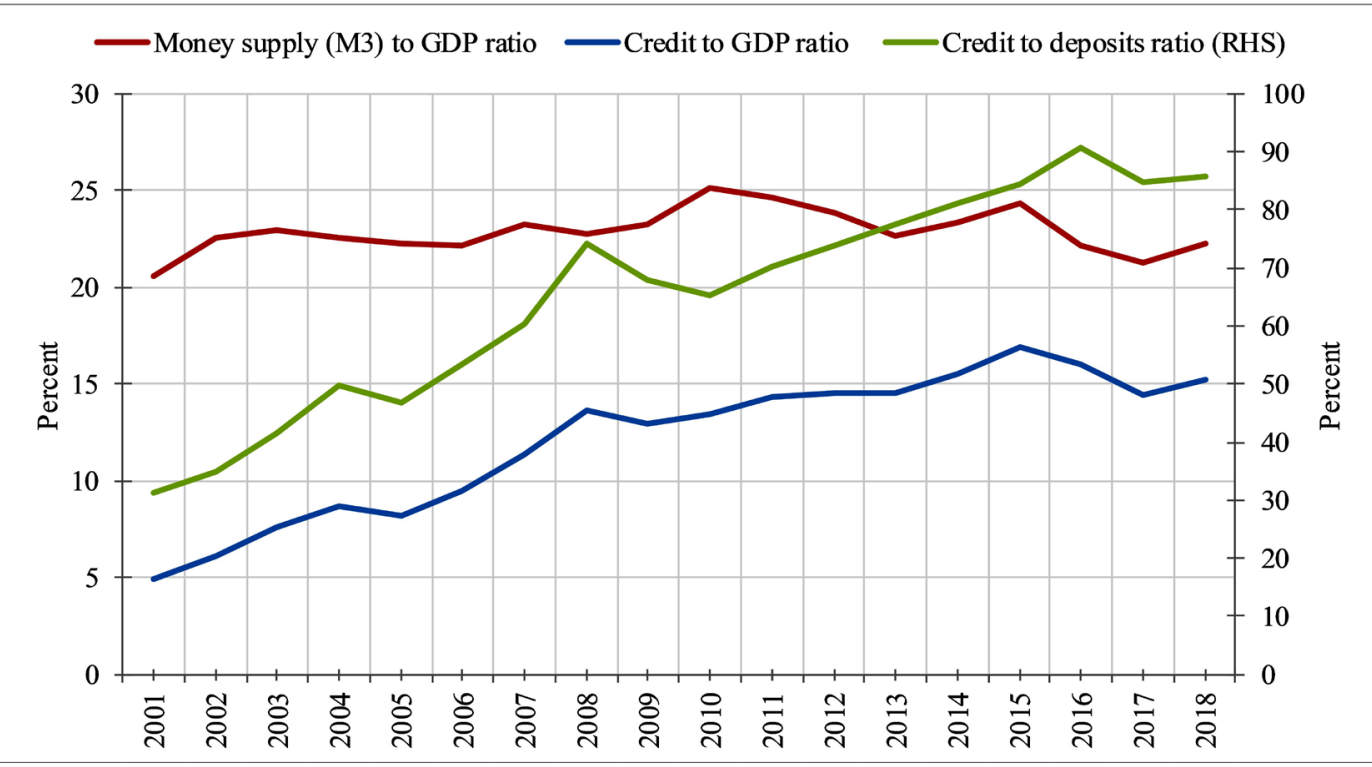

Source: Bank of Tanzania.

Figure 1. Financial sector deepening.

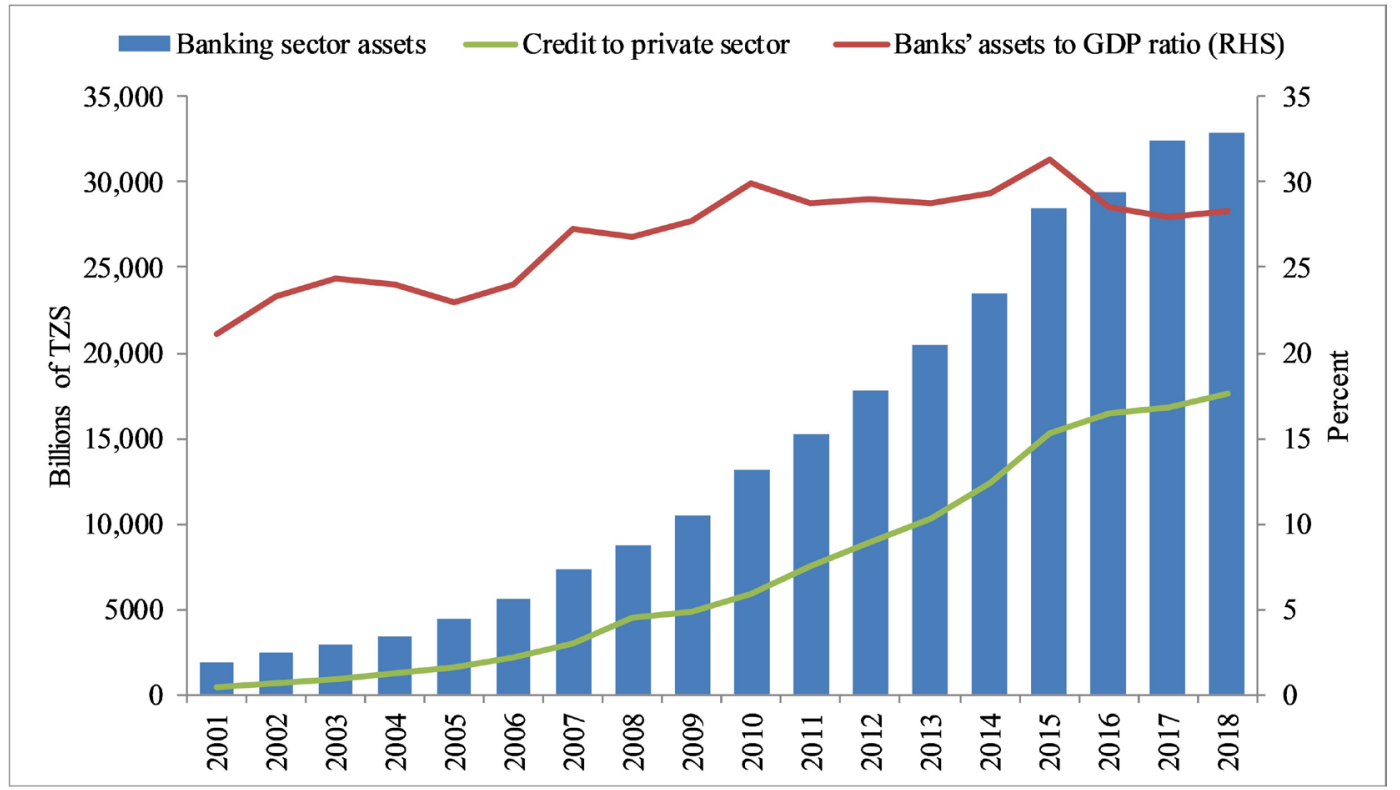

Source: Bank of Tanzania.

Figure 2. Development of banking sector assets.

the private sector largely in support of personal, trade and manufacturing activities. However, five large banks contributed nearly 52 of the total banks credit, which together with the banking sector reign, signal considerable concentration in the financial sector that may adversely affect credit supply and delivery of competitive interest rates.

\subsection{Evolution of Commercial Banks Interest Rates}

During the period of State control of the financial sector (1967-1991), credit was 


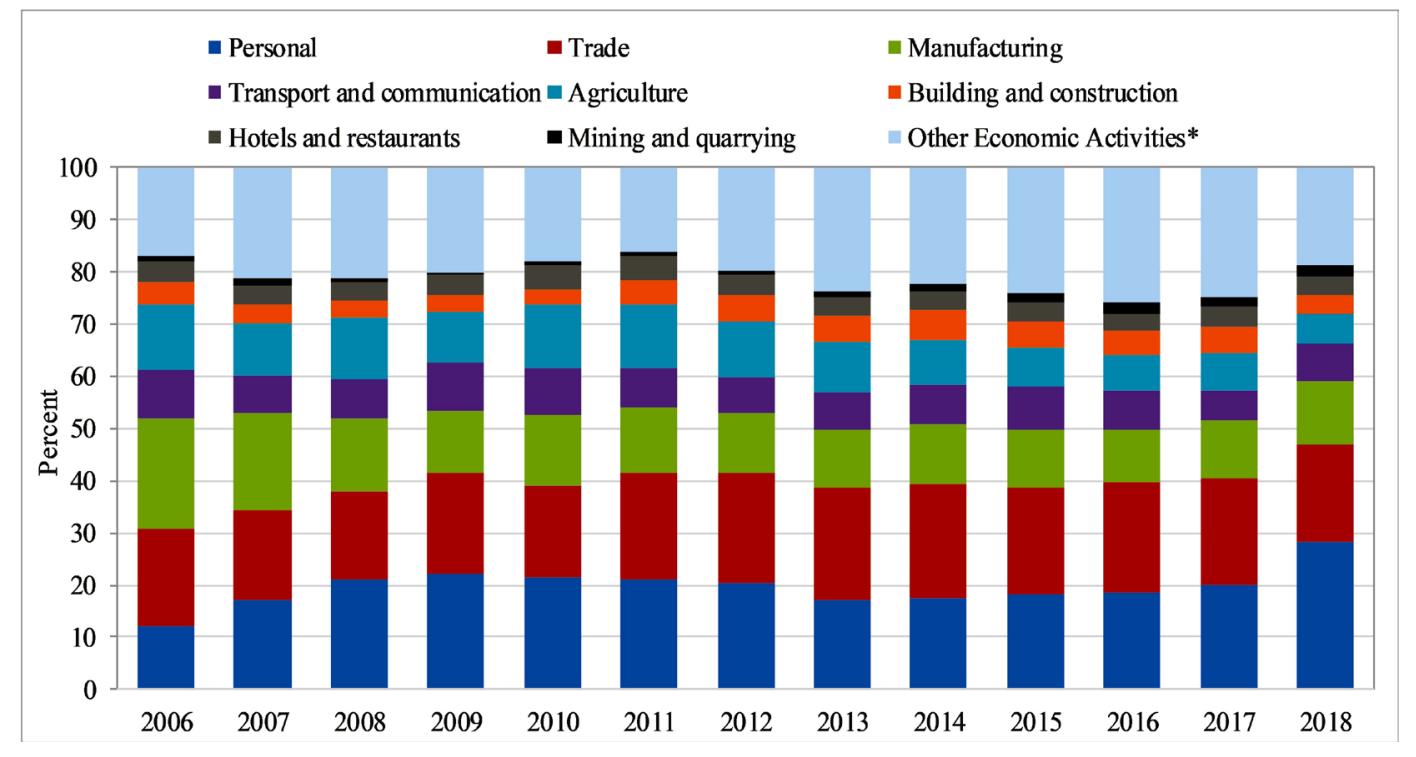

Source: Bank of Tanzania. Note: ${ }^{\star}$ These activities include, financial intermediaries, tourism, electricity, gas, water, mortgage, real estate, leasing, health \& education, warehousing \& storage, hunting, forest, and fishing.

Figure 3. Distribution of banks credit across economic activities.

directly rationed and allocated to specific sectors of the economy at preferential interest rates. Evidently, the adoption of the comprehensive economic reforms in 1986 saw interest rates rising suggesting a carry-on of the negative effects of delays in financial reforms partly related to a sustained pursuit of multiple monetary policy objectives and lack of requisite independence to discharge traditional central banking functions. With the start of comprehensive financial reforms in 1991, interest rates initially increased until when money markets were introduced in 1993/94, during which interest rates were completely liberalized. In 1995, BoT was mandated to carry out the traditional central bank role and functions, refocusing the monetary policy objectives towards the single primary objective of price stability (BoT, 1996). Here, the monetary policy is the main macroeconomic stabilization tool, largely via the money markets.

Specifically, banks' lending rates rose initially to an average rate of 36 percent in 1995 before taking a downward trend to about 17.8 percent in 2017, whereas average deposits rates edged upward to 27 percent and declined to about 10 percent in the similar period (Figure 4). The developments notwithstanding, interest rate spreads remained much higher during reform period particularly from 1998 and were associated with high and rigid lending interest rates. Compared with other East African Community (EAC) member countries (Burundi, Kenya, Rwanda and Uganda), bank lending rate in Tanzania over ten years to May 2019 was an average of 16.03 percent, being the second lowest after Kenya's 15.61 percent ${ }^{6}$. However, as portrayed in Figure 5, lending rates in Tanzania exhibited an upward shift starting December 2016, while trending above those of other EAC member countries except Uganda.

${ }^{6}$ In the same period, Uganda registered an average lending rate of 22.14 percent, Rwanda (17.05 percent) and Burundi (16.13 percent). 


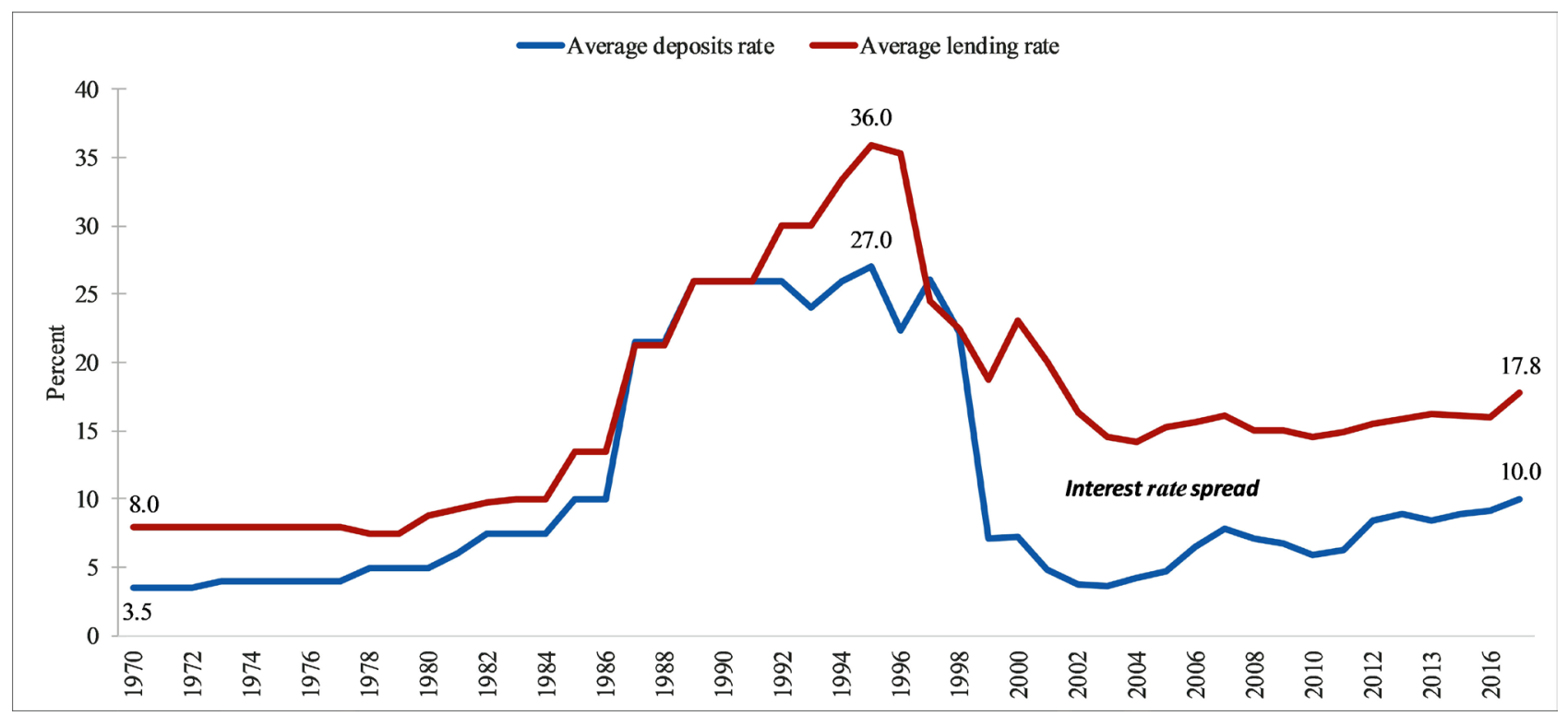

Source: Bank of Tanzania.

Figure 4. Commercial banks interest rates trends.

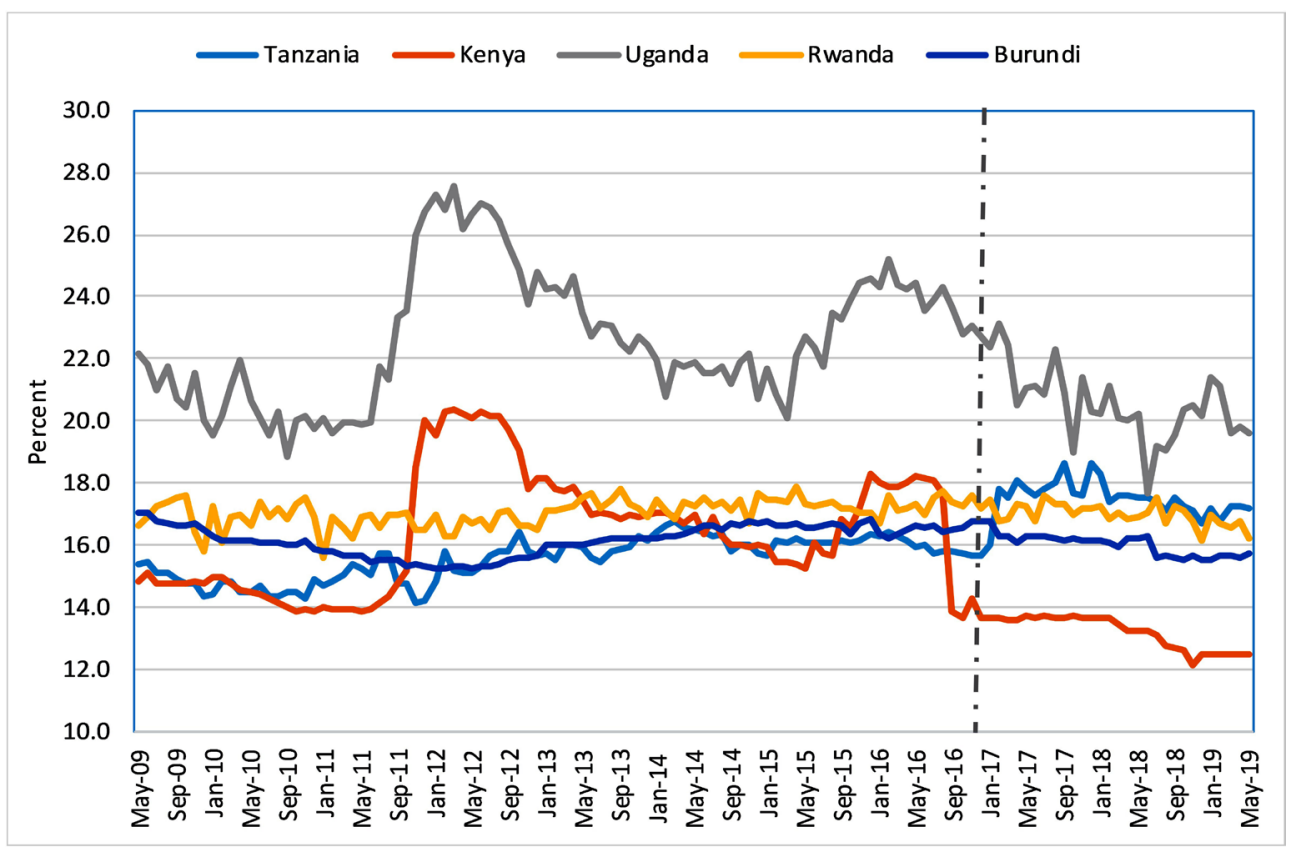

Source: EAC central banks.

Figure 5. EAC banks interest rates developments.

What could be explaining the observed tendency in lending interest rates in Tanzania? This is what this study endeavors to answer using banks' annual balance sheet data. To aid in answering the research questions and objectives, the literature review together with the study approach are taken up first.

\section{Literature Review}

The main theoretical underpinnings which underscore how interest rate is de- 
termined can be grouped under: the classical, loanable, and rational expectations theories. The classical approach stems from the fact that interest is the reward for the productive use of capital. Since physical capital is purchased with monetary funds, the rate of interest is taken to be the annual rate of return over money capital invested in physical capital assets. At this point, the savings investment theory is key, in which the rate of interest is determined by two forces of demand for and supply of capital. Whereas the demand for investable capital draws from investment decisions of the business sector, the supply of capital results from supplies of savings derived mainly from households (Friedman \& Kuttner, 1991; Rose, 2003).

Relatedly, loanable funds theory presupposes that interest rates are determined by supply of loanable funds and demand for credit; this is an improvement on the classical theory of interest ${ }^{7}$. This recognizes that money can play a disturbing role in the savings and investment processes and thereby causes variations in the level of income (Peng et al., 2002). The loanable funds theory considers the rate of interest as the function of four variables: savings, investment, the desire to hoard money and supply of money.

As for the rational expectations theory, it is based on the premise that people formulate expectations based on all the information that is available in the market. Thus, the best estimation for future interest rate is the current spot rate and that changes in interest rates are primarily due to unexpected information or changes in economic factors (Irungu, 2003). Rational expectations theory has limiting factors, though: the difficulty in gathering information and understanding how the public uses its information to form expectations (Caplan, 2000).

Two theoretical approaches in modeling determinants of interest rates are worth underscoring: the monopoly model by Klein (1971) and Monti (1972), and Ho and Saunders (1981)'s dealership model. The former approach assumes a profit maximizing firm whose primary business is to offer deposits and loan services. The monopolistic power of the bank in providing credit and deposits services in the market can somehow affect the operation of the businesses. In contrast, the dealership model views a bank not as a firm but as an intermediary between firms and households. The intermediation operations lead to uncertainty in the bank resulting from lack of coordination between the deposits and credit (loans) that leads to interest rate risk. Uncertainty may also arise from default by borrowers. Since, the bank does not have full information about its customers, this increases the likelihood of default that exposes the bank to credit risk. The more the bank faces credit risk, the more it widens its interest rate spread to avoid credit risk partly by increasing the lending rate.

Some other variables have also featured in similar studies that have modeled factors influencing lending interest rates in which deposits interest rate is treated

${ }^{7}$ According to Turnovsky (1985), loanable funds are the sums of money supplied and demanded at any time in the money market, where: funds available for lending are influenced by the savings of the people and the additions to the money supply (normally through credit creation by banks), while demand for loanable funds is determined by the need for investment plus desire for hoarding. 
as an independent variable or when the interest rates spread (the difference between lending and deposits interest rates) is instead treated as endogenous to the model. The explanatory factors can be categorized in three categories: 1) individual bank-specific factors, including operating or administrative costs, non-performing loans, return on assets, structure of the balance sheet, non-interest income or non-core revenues, bank size, and bank liquidity; 2) aspects specific to the banking industry comprising the degree of competition or market concentration, regulatory requirements such as statutory reserve requirements or regulated minimum deposit rates and; 3) macroeconomic indicators like growth rate of gross domestic product (GDP), inflation rate and taxes.

While some studies have focused on one category of the factors, others considered two or all the three categories of factors. Differences also exist in type of data and modeling techniques-i.e. time series against panel data approaches. Generally, mixed results are evident, suggesting a wide range of factors in explaining movements in banks' lending interest rates (see for example, Chodechai, 2004; Chirwa \& Mlachila, 2004; Cihak, 2004; Grenade, 2007; Gambacorta, 2008; Olokoyo, 2011; Siddique, 2012; Georgievska et al., 2011; Aikael et al., 2011; Were \& Wambua, 2013; Mbao et al., 2014; Manamba, 2014; Matemilola et al., 2015).

Using cross section and panel data, for example, studies such as Cihak (2004); Gambacorta (2008); Georgievska et al. (2011); Mbao et al. (2014) underscore the importance of bank size, liquidity, capital adequacy, foreign ownership, market share, non-performing loans, banks' costs, deposit rates, interest rate volatility, bank efficiency, credit and interest risks, and permanent changes in income in explaining lending interest rate variation. As for time series-based studies, Matemilola et al. (2015), used the momentum threshold autoregressive and asymmetric error correction models and found that bank lending rate adjusts to a decrease in the money market rate in South Africa. However, commercial banks adjust their lending rate downward but the lending rate appears rigid upward supporting the customer reaction proposition.

In Tanzania, Manamba (2014) focused on co-integration analysis using macro-level quarterly data covering 1986-2013 period and found that, interest rate spreads are significantly determined by lack of competition among financial institutions; existence of diseconomies of scale in the financial system; and that, as proportion of liquid assets increases the bank liquidity risk decreases, leading to lower interest rate spreads. Aikael et al. (2011) also use quarterly macro-level data and a co-integration and error correction model to establish relative importance of macroeconomic and regulatory factors in explaining persistence of interest rate spreads in Tanzania. The results reveal that interest rate spreads in Tanzania are strongly influenced by net government borrowing from commercial banks, development of the banking sector, statutory minimum reserve requirement and the discount rate.

The current study differs from the previous studies on Tanzania in two ways: 
first, it incorporates bank-level information, and considers other relevant factors such as operating costs, bank size and ownership structure, as well as monetary policy effects. Second, it extends data to 2017 making it possible to capture effects of the protracted reforms in the financial sector.

\section{Methodology}

Duo approaches are followed in this study to track the determinants of bank lending interest rates in Tanzania. First, lending interest rates are decomposed to identify contribution of specific accounting factors at the level of peer groups of banks as in Cihak and Podpiera (2005). The second technique involves econometric estimation with the lending interest rates treated as endogenous at bank-by-bank level (see for example, Cihak \& Podpiera, 2005; Samahiya \& Kaakunga, 2011; Ongeri, 2012; Were \& Wambua, 2013; Ahokpossi, 2013; and Nanjunga et al., 2016).

\subsection{Interest Rates Decomposition}

Interest rates decomposition is undertaken along two main banking institutions' characteristics or groups: size (small, medium and large) and ownership structure (local and foreign banks). The asset draining components are then analyzed over 2005 to 17 due to data unavailability. The main components considered in this study are operating costs, deposits interest rate (cost of funds), non-performing loans, provision for bad debts and SMR. The variables are derived as explained in Annex 1.

A contribution of a cost component in each category of banks is computed by multiplying the weight of the average value of a component by average lending rate in a specific period as shown in Equation (1). The weight is obtained by dividing the value of the component by the sum of values of all components in a group.

$$
C C_{i j t}=w_{i j t} L R_{j t},
$$

where, $c c_{i j t}$ is contribution of component $i$ in group $j$, period $t ; w$, weight of component $i$ in group $j$, period $t ; L R$, average lending rate in group $j$, period $t$; while $i, j=1, \cdots, 5$ and $t=1, \cdots, 4$.

\subsection{Econometric Model}

The starting point for panel data estimators is pooled ordinary least squares (OLS), which assumes away fixed effects or parameters (cross-section specific and time-invariant component) and non-fixed parameters, i.e. indiscriminate drawings from a certain probability distribution (random effects). If the assumption holds that the unobservable individual bank-specific effects are not very different, pooled OLS estimations is the most simple and efficient method for panel data analysis (Onuonga, 2014). This approach has been found to be inadequate, so that further estimations and tests are usually recommended with the view to accounting for fixed and random effects of the data (Greene, 2007; Cottrell \& Jack, 2016). The rule of thumb is that, if the panel compares observa- 
tions on a fixed and relatively small set of units of interest (say, banks), there is a presumption in favor of fixed effects. If it compares observations on a large number of randomly selected individual units (in this case, banks), there is a presumption in favor of random effects. The advice is followed in this study.

In equation form, the pooled OLS may be specified as:

$$
Y_{i t}=X_{i t} \beta+u_{i t} \text {, }
$$

with $Y_{i t}$ being the observations on the dependent variable for cross-sectional unit $i$ in period $t ; X_{i t}$, a vector of independent variables; and $u_{i t}$ is an error term specific for each unit over the period. The fixed and random effects models decompose the unitary pooled error term, $u_{i t}$. For the fixed effects model, decomposition is such that: $u_{i t}=\alpha_{i}+\varepsilon_{i t}$, where $\alpha_{i}$ is unit specific and time-invariant component, and $\varepsilon_{i t}$ is observation specific error term. Unlike the fixed effect model, where $\alpha_{i t}$ are treated as fixed parameters, random effect model treats them as random drawings from a given probability distribution $\left(v_{i}\right)$. Therefore, fixed and random models can be written as in Equations (3) and (4):

$$
\begin{aligned}
& Y_{i t}=X_{i t} \beta+\alpha_{i}+\varepsilon_{i t}, \\
& Y_{i t}=X_{i t} \beta+v_{i}+\varepsilon_{i t} .
\end{aligned}
$$

In modeling, the endogenous variable is bank lending interest rates, while explanatory variables comprise bank characteristics, industry-wide and macroeconomic factors as summarized in Annex 1. In answering the research objectives, a factor is considered to be useful in explaining movement in bank lending interest rates if it is statistically significant at the conversional test statistics (i.e. $1 \%$ or $5 \%$ or $10 \%$ ) and bears the expected sign. The relative importance is evaluated basing on the magnitude of the factor coefficients or share of the factor for the case of lending rates decomposition.

Bank level annual data are employed spanning the period 2001 to 2017, mainly drawn from annual financial statements of commercial banks, community banks, microfinance institutions and development finance institutions, which were in operation during the study period. This is a population of sixty institutions some of which have information over 17 years. Separate estimations are made to account for differences across ownership structure (local banks vis-à-vis foreign banks); and size (small banks vis-à-vis medium and large banks). Share of assets to the industry's total is used to separate banks across size categories. A large bank is the one with assets market share greater than or equal to 4 percent; a medium size bank, assets share of less than 4 percent but greater than one percent; and a small bank has assets share of less than 1 percent of the industry assets.

\section{Estimation and Discussion of Study Findings}

\subsection{Diagnostic Tests}

\subsubsection{Descriptive and Correlation Statistics}

Table 1 summarizes descriptive statistics of the variables of interest spanning the 
Table 1. Descriptive statistics.

\begin{tabular}{cccccc}
\hline Variable & Obs & Mean & Std. Dev. & Min & Max \\
\hline il & 654 & 15.1 & 6.4 & 0.3 & 61.8 \\
id & 631 & 8.2 & 3.7 & 0.6 & 17.3 \\
ras & 674 & -0.1 & 7.0 & -63.1 & 22.3 \\
opcr & 540 & 8.2 & 6.9 & 0.3 & 78.6 \\
nplr & 495 & 10.2 & 13.0 & 0.1 & 100.0 \\
siz & 702 & 2.4 & 5.4 & 0.0 & 73.9 \\
liqr & 697 & 27.5 & 22.5 & 1.5 & 353.2 \\
provr & 499 & 2.1 & 8.2 & -18.1 & 165.0 \\
smr & 1020 & 9.8 & 0.6 & 8.0 & 10.0 \\
rgdp & 1020 & 6.8 & 0.6 & 5.1 & 7.8 \\
infl & 1020 & 7.4 & 3.3 & 4.4 & 16.0 \\
itbl & 1020 & 10.2 & 3.7 & 3.9 & 16.2 \\
hhi_as & 1020 & 1423.1 & 1321.7 & 842.4 & 5568.3 \\
\hline
\end{tabular}

Source: Authors' computation.

period 2001 to 2017. Banks' lending interest rates (il) range from a minimum rate of 0.3 percent to a maximum rate of 61.0 percent with a relatively high variation from the mean of 6.4 compared to deposits interest rates with a standard deviation of 3.7, while deposits rate (id) ranged from a low rate of 0.6 percent and high rate of 17.3 percent. However, the variation in banks' interest rates is much less compared to those of some decision variables. Variables with high deviation from the mean are ratios of market concentration (hhi_as), liquid assets (liqr), non-performing loans (nplr), provision for bad loans (provr), operating costs (opcr) and bank size (siz). In contrast, macroeconomic variables (inflation, infl; and real GDP, rgdp); and Treasury bill interest rate (itbl), a proxy of monetary policy rate, have far lower standard deviations pointing to lesser risk. Owing to different standard deviations, the decision (explanatory) variables may have a varying impact on the dependent variable (lending rate).

Further analysis using correlation coefficients, as captured in Table 2, suggest a relatively high and positive relationship of bank lending interest rates with operating costs (32.5 percent) and SMR ratio (23 percent), whereas a negative relationship is evident with return on assets (23.3 percent). Correlation with deposits rate, market concentration, policy rate, size and liquidity strength indicators, as well as macroeconomic variables bear the hypothesized signs, but weak. Meanwhile correlation across independent variables is generally low except for operating costs and return on assets which have a correlation coefficient of 0.763 . With these mixed descriptive results, further enquiry is made using lending rates decomposition. Panel data econometric estimation approach is also important to determine the causal effect of the explanatory variables on the dependent variable. 
Table 2. Correlation matrix.

\begin{tabular}{|c|c|c|c|c|c|c|c|c|c|c|c|c|c|}
\hline & il & id & ras & opcr & nplr & siz & liqr & provr & $\mathrm{smr}$ & rgdp & infl & itbl & hhi_as \\
\hline il & 1 & & & & & & & & & & & & \\
\hline id & 0.054 & 1 & & & & & & & & & & & \\
\hline ras & -0.233 & 0.074 & 1 & & & & & & & & & & \\
\hline opcr & 0.325 & -0.304 & -0.763 & 1 & & & & & & & & & \\
\hline nplr & 0.057 & 0.006 & -0.369 & 0.271 & 1 & & & & & & & & \\
\hline siz & -0.093 & -0.214 & 0.292 & -0.206 & -0.109 & 1 & & & & & & & \\
\hline liqr & -0.071 & -0.144 & 0.090 & -0.037 & 0.028 & 0.084 & 1 & & & & & & \\
\hline provr & 0.024 & 0.063 & -0.222 & 0.053 & 0.081 & -0.043 & -0.020 & 1 & & & & & \\
\hline smr & -0.230 & -0.224 & 0.142 & -0.067 & -0.092 & 0.045 & -0.097 & -0.145 & 1 & & & & \\
\hline rgdp & 0.094 & 0.067 & -0.004 & 0.027 & 0.044 & -0.007 & 0.053 & 0.055 & -0.225 & 1 & & & \\
\hline infl & -0.155 & -0.157 & 0.084 & -0.081 & -0.120 & 0.028 & -0.085 & -0.086 & 0.376 & -0.812 & 1 & & \\
\hline itbl & 0.091 & 0.252 & -0.102 & 0.129 & 0.030 & -0.042 & -0.037 & -0.031 & -0.085 & 0.041 & -0.173 & 1 & \\
\hline hhi_as & -0.092 & -0.302 & 0.227 & -0.184 & -0.098 & 0.076 & 0.064 & -0.004 & 0.379 & 0.018 & 0.162 & -0.485 & 1 \\
\hline
\end{tabular}

Source: Authors' computation.

\subsubsection{Unit Root Tests}

Hadri LM test was employed to test for stationarity of all panels, with the null hypothesis (Ho): "All panels are stationary". Since the test requires strongly balanced data only tests for SMR ratio, real GDP, inflation, treasury bill rate, and market concentration indicators are reported. The results are as summarized in Table 3 and, they indicate that the variables are stationary at 1 percent level. This information together with the fact that the remaining variables are in ratios or rates, suggest that the variables may be considered at their levels or growth rates in econometric estimation.

\subsection{Estimations and Discussion}

\subsubsection{Decomposition Results}

Here, we identify contribution of specific accounting components (factors) at the level of peer groups of banks. Tables 4-6 summarize results obtained through decomposition of lending rates along banks asset draining components. SMR, operating costs, costs of funds, and non-performing loans (NPLs) appear to account for the largest chunk of the industry lending rates. Provision for bad debts is far less important. This trend carries on with the decomposition of interest rates spread (see, Annex 2).

Analysis across ownership structure reveals that lending rates during 2005 to 2017 increased across local and foreign owned banks, with foreign banks exhibiting a faster growth than their counterpart, particularly from the 2009-12 sub-period. Local banks average lending rates rose from 7.4 percent to 10.4 percent in 2014-17 compared to those of foreign banks which increased from an average of 7.4 percent to 15.1 percent. The main driver was small banks whose 
Table 3. Panel root tests.

\begin{tabular}{ccccc}
\hline & Z-statistic & $p$-value & Level of significance & Trend \\
\hline smr & 12.724 & 0.000 & $1 \%$ & Not included \\
rgdp & 2.538 & 0.006 & $1 \%$ & Included \\
infl & 24.346 & 0.000 & $1 \%$ & Included \\
itbl & 3.638 & 0.000 & $1 \%$ & Included \\
hhi_as & 20.542 & 0.000 & $1 \%$ & Included \\
\hline
\end{tabular}

Source: Authors' computations.

Table 4. Decomposition of industry lending rates.

\begin{tabular}{|c|c|c|c|c|c|c|c|c|c|}
\hline \multirow{2}{*}{ Category } & \multicolumn{4}{|c|}{ Contribution in percentage points } & \multicolumn{4}{|c|}{ Contribution in percent } & \multirow{2}{*}{$\begin{array}{l}\text { Average } \\
2005-17\end{array}$} \\
\hline & 2005-07 & $2008-10$ & 2011-13 & 2014-17 & $2005-07$ & $2008-10$ & 2011-13 & $2014-17$ & \\
\hline Interest rate spread & 15.7 & 14.9 & 15.5 & 16.5 & & & & & \\
\hline Operating costs/assets & 3.3 & 3.0 & 3.9 & 3.9 & 21.3 & 20.5 & 25.4 & 23.7 & 22.7 \\
\hline NPLs/gross loans & 2.2 & 3.4 & 3.2 & 3.8 & 13.9 & 22.6 & 20.8 & 23.2 & 20.1 \\
\hline Cost of funds (deposits rate) & 3.5 & 3.0 & 3.5 & 3.9 & 22.2 & 20.4 & 22.4 & 23.3 & 22.1 \\
\hline Provision for bad debts/gross loans & 1.0 & 0.8 & 0.4 & 1.1 & 6.7 & 5.6 & 2.8 & 6.9 & 5.5 \\
\hline SMR ratio & 5.6 & 4.6 & 4.4 & 3.8 & 35.8 & 30.8 & 28.6 & 23.0 & 29.6 \\
\hline
\end{tabular}

Source: Authors' computation.

Table 5. Decomposition of lending rates by bank ownership category.

\begin{tabular}{|c|c|c|c|c|c|c|c|c|c|}
\hline \multirow{2}{*}{ Category } & \multicolumn{4}{|c|}{ Controbution in percentage points } & \multicolumn{4}{|c|}{ Contribution in percent } & \multirow{2}{*}{$\begin{array}{l}\text { Average } \\
2005-17\end{array}$} \\
\hline & 2005-07 & $2008-10$ & 2011-13 & 2014-17 & $2005-07$ & $2008-10$ & 2011-13 & 2014-17 & \\
\hline \multicolumn{10}{|l|}{ Local banks } \\
\hline Lending rate & 5.2 & 7.4 & 8.9 & 10.4 & & & & & \\
\hline Operating costs/assets & 1.4 & 2.1 & 2.7 & 3.1 & 27.3 & 28.3 & 29.8 & 29.5 & 28.7 \\
\hline Cost of funds (deposits rate) & 0.4 & 0.7 & 0.9 & 1.2 & 7.4 & 8.8 & 10.2 & 11.8 & 9.6 \\
\hline NPLs/gross loans & 0.9 & 1.8 & 2.6 & 3.5 & 16.3 & 24.3 & 28.5 & 33.9 & 25.8 \\
\hline Provision for bad debts/gross loans & 0.5 & 0.4 & 0.0 & 0.3 & 8.7 & 5.8 & 0.3 & 3.2 & 4.5 \\
\hline SMR ratio & 2.1 & 2.4 & 2.8 & 2.2 & 40.4 & 32.9 & 31.1 & 21.6 & 31.5 \\
\hline \multicolumn{10}{|l|}{ Foreign banks } \\
\hline Lending rate & 7.0 & 7.4 & 11.0 & 15.1 & & & & & \\
\hline Operating costs/assets & 1.5 & 1.4 & 2.9 & 3.1 & 22.0 & 19.1 & 26.6 & 20.3 & 22.0 \\
\hline Cost of funds (deposits rate) & 0.9 & 1.1 & 2.0 & 3.2 & 13.1 & 14.5 & 17.8 & 20.9 & 16.6 \\
\hline NPLs/gross loans & 1.3 & 1.9 & 2.2 & 3.8 & 17.9 & 25.7 & 20.0 & 24.9 & 22.1 \\
\hline Provision for bad debts/gross loans & 0.5 & 0.5 & 0.5 & 1.4 & 6.9 & 6.4 & 4.4 & 9.1 & 6.7 \\
\hline SMR ratio & 2.8 & 2.5 & 3.4 & 3.7 & 40.1 & 34.2 & 31.2 & 24.7 & 32.6 \\
\hline
\end{tabular}

Source: Authors' computation. 
Table 6. Decomposition of lending rates by bank size category.

\begin{tabular}{|c|c|c|c|c|c|c|c|c|c|}
\hline \multirow{2}{*}{ Category } & \multicolumn{4}{|c|}{ Contribution in percentage points } & \multicolumn{4}{|c|}{ Contribution in percent } & \multirow{2}{*}{$\begin{array}{l}\text { Average } \\
2005-17\end{array}$} \\
\hline & 2005-07 & $2008-10$ & 2011-13 & 2014-17 & $2005-07$ & 2008-10 & 2011-13 & 2014-17 & \\
\hline \multicolumn{10}{|l|}{ Large banks } \\
\hline Lending rate & 12.3 & 13.2 & 14.8 & 16.3 & & & & & \\
\hline Operating costs/assets & 2.3 & 2.4 & 2.9 & 3.4 & 18.6 & 17.8 & 19.3 & 21.0 & 19.2 \\
\hline Cost of funds (deposits rate) & 2.2 & 2.6 & 3.0 & 3.5 & 17.9 & 19.8 & 20.0 & 21.2 & 19.7 \\
\hline NPLs/gross loans & 2.3 & 3.2 & 3.4 & 4.1 & 19.0 & 23.9 & 22.8 & 25.2 & 22.7 \\
\hline Provision for bad debts/gross loans & 0.8 & 0.4 & 0.8 & 0.7 & 6.6 & 3.4 & 5.6 & 4.3 & 5.0 \\
\hline SMR ratio & 4.7 & 4.6 & 4.8 & 4.6 & 37.9 & 35.2 & 32.2 & 28.3 & 33.4 \\
\hline \multicolumn{10}{|l|}{ Medium size banks } \\
\hline Lending rate & 10.5 & 13.2 & 14.7 & 16.3 & & & & & \\
\hline Operating costs/assets & 2.2 & 2.2 & 2.4 & 2.3 & 20.7 & 16.5 & 16.5 & 14.3 & 17.0 \\
\hline Cost of funds (deposits rate) & 2.1 & 2.4 & 3.1 & 3.8 & 19.7 & 18.3 & 20.8 & 23.6 & 20.6 \\
\hline NPLs/gross loans & 1.3 & 3.3 & 4.3 & 5.1 & 12.7 & 25.0 & 29.0 & 31.6 & 24.6 \\
\hline Provision for bad debts/gross loans & 0.5 & 1.0 & 0.4 & 0.9 & 4.4 & 7.4 & 2.8 & 5.7 & 5.1 \\
\hline SMR ratio & 4.5 & 4.3 & 4.6 & 4.0 & 42.5 & 32.8 & 31.0 & 24.8 & 32.8 \\
\hline \multicolumn{10}{|l|}{ Small size banks } \\
\hline Lending rate & 3.5 & 4.3 & 7.4 & 10.9 & & & & & \\
\hline Operating costs/assets & 1.0 & 1.3 & 2.7 & 3.2 & 28.2 & 29.7 & 36.8 & 29.0 & 30.9 \\
\hline Cost of funds (deposits rate) & 0.2 & 0.3 & 0.7 & 1.4 & 5.1 & 7.5 & 10.1 & 12.5 & 8.8 \\
\hline NPLs/gross loans & 0.7 & 1.1 & 1.5 & 3.1 & 19.0 & 24.6 & 20.9 & 28.9 & 23.3 \\
\hline Provision for bad debts/gross loans & 0.4 & 0.2 & 0.2 & 0.9 & 10.5 & 5.3 & 2.0 & 8.4 & 6.6 \\
\hline SMR ratio & 1.3 & 1.4 & 2.2 & 2.3 & 37.2 & 32.9 & 30.2 & 21.2 & 30.4 \\
\hline
\end{tabular}

Source: Authors' computation.

average lending rate rose to 10.9 percent from 3.5 percent in 2005-08 due to operating costs, non-performing loans, and costs of funds measured by deposits rate, which together accounted for 70.4 percent of the lending rates in this category in 2014-17. The three factors also play a great role in other categories contributing on average 69.5 percent and 67.4 percent of the lending rates in medium and large banks sub-groups, respectively. SMR ratio appears to play an important role in lending rates across bank categories, but its share has been declining overtime consistent with the expansionary monetary policy measures pursued since 2014 to spur credit growth in which SMR ratio was reduced for the first time to 7.0 percent from the long prevailing rate of 10.0 percent.

The main reasons behind cost of funds could partly be due to increased banks' competition for deposits partly following tight liquidity conditions experienced by banks especially from 2016, largely due to cumulative impact of substantial decline in net foreign budgetary inflows, transfer of public institutions' deposits from commercial banks to the Bank of Tanzania and heightened expenditure management. This trend prompted for pursuance of accommodative monetary policy with a view to increase banks liquidity and support growth of credit to the private sector. Meanwhile, non-performing loans increased to 10.5 percent in June 2017 from 6.4 percent in June 2008 contributed by a combination of in- 
cluding global financial crises; credit screening weaknesses; a decrease in supply of loans partly contributed by factors such as liquidity tightness, and decline of effective demand for loans attributed to domestic fiscal consolidation and disciple enhancement measures; drought that adversely affected agricultural production (especially in 2015 to 2016); capital enhancement measures including adoption of capital charge for operational risk, introduction of capital buffer of 2.5 percent and anticipation of increased provision following due to adoption of IFRS 9.

The high operating costs is largely driven by costs related to employees' salaries and benefits which accounted for an average of 43.7 percent of the banking industry's operating costs in the five years to 2017 and have been increasing overtime (Table 7). Other notable costs components are rental expenses on premises and equipment, depreciation of premises and equipment, and utilities expenses, which together contributed another 16.2 percent in the banking industry operating costs. Employees' salaries and benefits costs are much higher for small banks at 44.4 percent of operating costs compared to 42.5 percent and 43.9 percent for medium size and large banks, respectively (see, Annex 3).

\subsubsection{Econometric Results}

In this sub-section, further enquiry is done covering components used in the interest rates decomposition exercise and other industry-level and macroeconomic variables. Since the decomposition of lending rates and interest rates spread yield qualitatively similar results, econometric estimations are only made with lending rates as an endogenous variable. Table 8 captures general model results

Table 7. Percentage shares of drivers of banks operating costs.

\begin{tabular}{|c|c|c|c|c|c|c|c|c|c|c|c|c|c|}
\hline \multirow[b]{2}{*}{ Cost component } & \multicolumn{13}{|c|}{ Percentage Share in Total Operating Costs of Banks } \\
\hline & 2006 & 2007 & 2008 & 2009 & 2010 & 2011 & 2012 & 2013 & 2014 & 2015 & 2016 & 2017 & $\begin{array}{l}\text { Average } \\
\text { 2013-17 }\end{array}$ \\
\hline Employees salaries and benefits & 40.0 & 40.8 & 41.0 & 42.8 & 40.4 & 41.5 & 42.2 & 43.0 & 43.9 & 43.4 & 43.9 & 44.2 & 43.7 \\
\hline Rental expenses on premises and equipment & 5.0 & 5.1 & 5.0 & 5.6 & 5.8 & 6.3 & 6.2 & 6.2 & 6.0 & 6.6 & 7.2 & 7.0 & 6.6 \\
\hline Depreciation-premises and equipment & 6.0 & 6.1 & 6.5 & 7.3 & 7.4 & 7.7 & 8.7 & 7.3 & 6.8 & 5.9 & 6.2 & 6.7 & 6.6 \\
\hline Utilities expenses & 3.8 & 2.8 & 3.1 & 4.0 & 3.1 & 3.1 & 3.4 & 3.3 & 3.2 & 2.7 & 2.8 & 3.1 & 3.0 \\
\hline Insurance & 2.2 & 2.3 & 2.1 & 2.2 & 2.3 & 2.7 & 2.3 & 2.4 & 2.4 & 2.4 & 2.4 & 2.5 & 2.4 \\
\hline Taxes and license fees & 1.8 & 1.4 & 1.0 & 1.2 & 1.9 & 1.8 & 1.9 & 1.4 & 2.0 & 2.3 & 2.8 & 2.4 & 2.2 \\
\hline Other professional fees & 1.4 & 2.3 & 0.7 & 0.8 & 1.2 & 1.7 & 1.9 & 1.3 & 1.8 & 1.6 & 1.6 & 1.4 & 1.5 \\
\hline Amortization-leasehold rights and improvements & 0.5 & 0.5 & 0.6 & 0.6 & 0.6 & 0.7 & 0.7 & 0.9 & 1.0 & 0.9 & 1.0 & 1.2 & 1.0 \\
\hline $\begin{array}{l}\text { Supervision and inspection } \\
\text { fees/BOT charges/penalties }\end{array}$ & 0.0 & 0.0 & 0.0 & 0.0 & 0.0 & 0.0 & 0.0 & 0.0 & 0.1 & 0.0 & 0.0 & 0.0 & 0.0 \\
\hline Management fees & 0.8 & 1.4 & 2.1 & -0.5 & 0.6 & 1.5 & 1.2 & 1.3 & 1.3 & 1.6 & 0.0 & 0.6 & 1.0 \\
\hline Auditors fees & 0.6 & 0.4 & 0.4 & 0.5 & 0.5 & 0.4 & 0.4 & 0.4 & 0.4 & 0.4 & 0.4 & 0.5 & 0.4 \\
\hline Foreclosure and litigation expenses & 0.3 & 0.3 & 0.3 & 0.3 & 0.3 & 0.3 & 0.2 & 0.2 & 0.2 & 0.2 & 0.3 & 0.2 & 0.2 \\
\hline Others & 37.5 & 36.7 & 37.1 & 35.2 & 35.8 & 32.3 & 30.7 & 32.5 & 30.9 & 31.9 & 31.3 & 30.2 & 31.4 \\
\hline
\end{tabular}

Source: Authors' computation. 
Table 8. General model results.

\begin{tabular}{|c|c|c|c|c|c|c|c|}
\hline \multicolumn{7}{|c|}{ Dependent variable: Lending interest rate } & \multirow{4}{*}{$\begin{array}{l}\text { Average values } \\
\text { of significant } \\
\text { coefficients }\end{array}$} \\
\hline \multirow{3}{*}{$\begin{array}{c}\text { Independent } \\
\text { variable }\end{array}$} & \multicolumn{6}{|c|}{ Model 1: All banks } & \\
\hline & \multicolumn{2}{|c|}{ Weighted Least Squares } & \multicolumn{2}{|c|}{ Fixed effect } & \multicolumn{2}{|c|}{ Random effect } & \\
\hline & No Lag & $1 \mathrm{Lag}$ & No Lag & $1 \mathrm{Lag}$ & No Lag & $1 \mathrm{Lag}$ & \\
\hline const & $15.944^{* * *}$ & $12.505^{\star}$ & $22.466^{* *}$ & 6.656 & $17.938^{\star *}$ & 8.543 & \\
\hline il & & -0.077 & & $-0.497^{\star}$ & & -0.108 & -0.497 \\
\hline id & $0.243^{* * *}$ & -0.142 & $0.269^{*}$ & 0.311 & $0.254^{\star *}$ & -0.281 & 0.255 \\
\hline ras & 0.089 & $0.277^{\star * *}$ & 0.074 & 0.144 & $0.109^{* * *}$ & 0.251 & 0.109 \\
\hline opcr & $0.332^{* * *}$ & $0.111^{* *}$ & $0.334^{* * *}$ & $0.268^{*}$ & 0.364 & 0.074 & 0.261 \\
\hline nplr & 0.012 & $0.094^{* * *}$ & -0.022 & 0.027 & -0.021 & 0.091 & 0.094 \\
\hline siz & 0.023 & $-0.226^{* * *}$ & -0.026 & -0.159 & 0.009 & $-0.349^{* * *}$ & -0.575 \\
\hline liqr & $-0.053^{\star *}$ & 0.021 & -0.05 & -0.018 & -0.041 & 0.001 & -0.053 \\
\hline provr & -0.026 & 0.005 & -0.027 & -0.031 & $-0.012^{\star * *}$ & 0.005 & -0.012 \\
\hline $\mathrm{smr}$ & $-1.120^{\star * *}$ & 0.148 & $-1.387^{* *}$ & 0.734 & -1.560 & 0.155 & -1.254 \\
\hline rgdp & -0.289 & 0.853 & -0.170 & 1.142 & -0.344 & 1.269 & \\
\hline infl & -0.151 & $0.372^{\star * *}$ & -0.122 & 0.291 & -0.129 & $0.492^{* *}$ & 0.432 \\
\hline itbl & 0.030 & $-0.197^{\star *}$ & 0.040 & -0.263 & $0.059^{* *}$ & -0.217 & -0.069 \\
\hline HHI_AS & $0.010^{* *}$ & -0.005 & 0.004 & -0.002 & 0.012 & -0.001 & 0.010 \\
\hline Adj $R^{2}$ & 0.241 & 0.207 & & & & & \\
\hline F-stastic & $10.346^{* * *}$ & $4.685^{* * *}$ & $\begin{array}{c}\mathrm{F}(12,59)= \\
4.252^{* * *}\end{array}$ & $\begin{array}{c}\mathrm{F}(13,52)= \\
2.465^{\star *}\end{array}$ & & & \\
\hline $\begin{array}{l}\text { Null } \\
\text { hypothesis }\end{array}$ & & & $\begin{array}{l}\text { Groups } \\
\text { common } \\
\text { intercept: } \\
\text { Welch F(59, } \\
91.1)=0.818 \text {; } \\
p \text {-value = } \\
0.794\end{array}$ & $\begin{array}{l}\text { Groups } \\
\text { common } \\
\text { intercept: Welch } \\
\mathrm{F}(52,44.8)= \\
1.392 ; p \text {-value }= \\
0.129\end{array}$ & $\begin{array}{l}\text { 1) Breusch-Pagan test: } \\
\text { Unit-specific error } \\
\text { variance }=0 \text {; } \\
\text { Chi-square }(1)= \\
0.0002, p \text {-value } 0.988 \text {. } \\
\text { Hausman test: GLS } \\
\text { estimates are } \\
\text { consistent; Chi-square } \\
(12)=26.99, p \text {-value } \\
0.008\end{array}$ & $\begin{array}{l}\text { 1) Breusch-Pagan test: } \\
\text { Unit-specific error } \\
\text { variance }=0 \text {; } \\
\text { Chi-square }(1)=4.277 \text {, } \\
p \text {-value } 0.039 . \\
\text { Hausman test: GLS } \\
\text { estimates are } \\
\text { consistent; Chi-square } \\
(13)=49.958, p \text {-value } \\
0.000\end{array}$ & \\
\hline
\end{tabular}

Source: Authors' computation. Note: ${ }^{\star * *}\left({ }^{* *}\right)^{\star}$ means significant at $1 \%(5 \%) 10 \%$. Robust (HAC) standard errors were used in weighted least squares and fixed effect estimations.

obtained by using three approaches: weighted least squares, fixed effects and random effects, all employing 60 cross-sessional units some of them observed over 17 years to 2017. Estimations allow for a lag to accommodate rigidity in the economy. For the former two approaches, estimation is made in robust (HAC) standard errors setting to take care of possible heteroskedasticity and autocorrelation in the data. The average results across all banks or bank categories are provided in Figure 6 and Table 9, while detailed individual econometric results are provided in Annex 4. The dependent variable is weighted average interest 


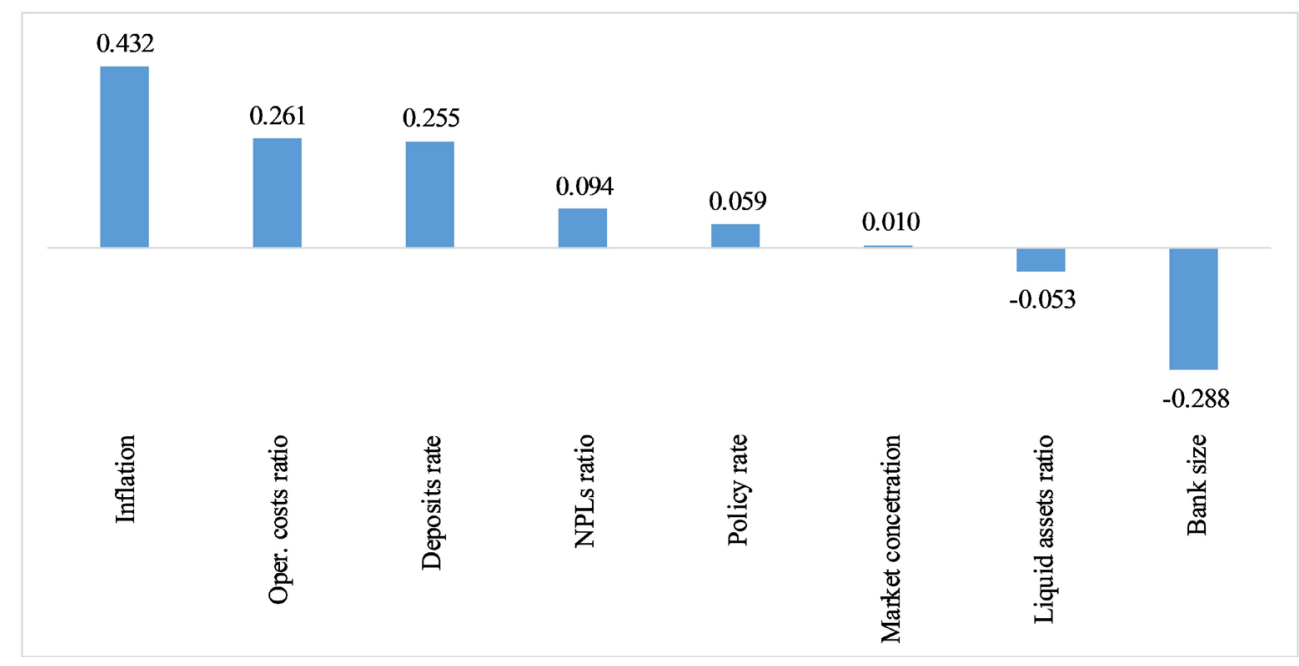

Source: Authors' computation.

Figure 6. Main determinants of lending rates using econometric approach.

Table 9. Average values of statistically significant coefficients across bank categories.

\begin{tabular}{cccccc}
\hline Variable & Local & Foreign & Small & Medium & Large \\
\hline il & 0.282 & & & -0.190 & 0.307 \\
id & -0.249 & 0.484 & 0.581 & 0.467 & -0.343 \\
ras & & 0.232 & 0.228 & 0.641 & 0.641 \\
opcr & & 0.498 & 0.312 & 1.620 & 0.943 \\
nplr & -0.101 & -0.074 & 0.070 & & 0.232 \\
siz & 0.249 & & -10.574 & -0.717 & 0.223 \\
liqr & 0.200 & -0.097 & -0.239 & -0.095 & 0.117 \\
provr & & & -1.009 & & \\
smr & 1.248 & -1.850 & -1.850 & -1.030 & -1.002 \\
rgdp & & & -1.036 & & -2.171 \\
infl & -0.360 & & -0.451 & & -0.364 \\
itbl & 0.325 & & & -0.452 & -0.257 \\
HHI_AS & 0.011 & 0.020 & 0.020 & 0.023 & 0.009 \\
\hline
\end{tabular}

Source: Authors' computation.

rates on banks loans (il). The explanatory variables are: operating cost/total assets (opcr); deposits interest rates (id), a proxy of cost of funds; return on assets (ras); non-performing loans/total loans (nplr); bank size (siz); liquid assets/total assets (lqr); treasury bill rate, a measure of monetary policy rate (itbl); statutory minimum requirement (smr); assets market concentration index (HHI_AS); inflation (infl); and growth rates of real gross domestic product (rgdp) ${ }^{8}$.

The findings indicate that operating costs, deposit rates (cost of funds), and inflation have a statistically significant positive effect on banks' lending rates, ${ }^{8}$ See, Annex 1 for details on expected signs. 
while bank size and level of liquidity have a negative influence. Although SMR ratio is statistically significant it puzzlingly bears a negative sign, implying that an increase in SMR ratio could lead to a decline in lending rates. Thought differently, the negative sign on SMR ratio coefficient could be a reflective of lag effect of active use of the instrument particularly in the second half of 1990s to control excess liquidity in the economy partly to reduce credit risk. Looking at the econometric results, this thinking could be more relevant to foreign owned banks than local banks. This is because one percent increases in SMR ratio would be accompanied by a rise in lending rates by an average of 1.248 percent for local banks compared to a decline of 1.85 percent for foreign banks. Noteworthy, the negative effect seems to outweigh the positive effect when banks are grouped along size (Table 9).

Basing on the general model results (Table 8), and sticking to only variables which are statistically significant and bear the expected signs, the main determinants of lending rates could be ranked as follows: inflation with an average positive impact of 0.432 on lending rates for a unit increase in inflation, followed by operating costs $(0.261)$, and deposits rate (0.255). Other factors with a positive effect are NPLs, policy rate, bank size, and market concentration. Bank size has the largest negative effect of 0.288 on lending rates (Figure 6).

The results along banks characteristics suggest that the most important factors for local banks are increase in SMR ratio, policy rate and market concentration, which tend to influence lending rate positively, and inflation that acts in the negative direction. In contrast, foreign banks' lending rates increase with a rise in operating costs, deposits rate (cost of funds), and market concentration, while a rise in banks liquid would lead to a decline in lending rates. A growth in cost of funds, operating costs, non-performing loans and market concentration also tend to lead to increase in lending rates by small banks while improvement in liquid strength and RGDP, as well as inflation would lower the cost of loans. Operating costs, deposits rate, and market concentration likewise matter for medium size banks in lending rate increase, whereas improvement in bank's size and liquid strength tend to influence lending rates negatively. For large banks, lending rates increase by 0.943 percent due to a percent increase in operating costs, while for non-performing loans it rises by 0.232 percent; 0.009 percent (market concentration), while lending rates decrease by 2.171 percent and 0.364 percent due to increases in inflation and RGDP by one percent, respectively.

The results on Tanzania corroborate the situation revealed in some other East African Community member states. According to the study by National Bank of Rwanda of 2018, the drivers of lending rates in Rwanda are operating costs, market concentration, provisions for bad debts, and deposits rate. In Kenya, the factors are operating costs, NPLs, inflation, interest caps, and liquidity level (Central Bank of Kenya, 2018).

\section{Conclusion and Policy Implications}

This study attempts to investigate the determinants of bank lending interest 
rates in Tanzania, largely targeting to ascertain the key determinants together with their relative importance. Both interest rates decomposition and econometric techniques are employed using banks' annual balance sheet data spanning the period 2001 to 2017.

Lending rates decomposition results suggest that the main drivers of bank lending rates are operating costs, non-performing loans; and costs of funds. The three factors accounted for 70.4 percent of small banks' average lending rates in 2014-17, while for medium and large banks; they constituted about 69.5 percent and 67.4 percent of the lending rates, respectively. SMR ratio appears to play an important role in all banks' lending rates, but its share has been declining overtime consistent with the expansionary monetary policy measures pursued since 2014. Econometric results point to a combination of factors that influence banks' lending rates. In particular, operating costs, cost of funds, and inflation have a statistically significant positive effect on bank lending rates, while bank size and level of liquidity have a negative influence. SMR ratio is statistically significant but bears unexpected negative sign except for locally owned banks. The negative sign on SMR ratio coefficient could reflect a lag effect of active use of the instrument particularly, in the second half of 1990s, to control excess liquidity in the economy. In relative importance, the main determinants of lending rates could be ranked as follows: inflation with an average positive impact of 0.432 on lending rates for a unit change in the variable, tailed by operating costs (0.261), and deposits rate (0.255). Other factors with a positive effect on banks lending rates are increase in NPLs, policy rate, and market concentration. Bank size has the largest negative effect of 0.288 for every unit increase in the variable. These factors are also significant but with some variation across bank categories.

The main reasons behind high deposits rates include increased banks' competition for deposits partly following tight liquidity conditions experienced by banks especially from 2016, largely due to cumulative impact of substantial decline in net foreign budgetary inflows, transfer of public institutions' deposits from commercial banks to the Bank of Tanzania and heightened expenditure management. Factors affecting non-performing loans comprise global financial crises; credit screening weaknesses; a decrease in supply of loans partly contributed by factors such as liquidity tightness, and decline of effective demand for loans ascribed to domestic fiscal consolidation and disciple enhancement measures; capital enhancement measures including adoption of capital charge for operational risk, introduction of capital buffer and anticipation of increased provision following due to adoption of IFRS 9. Meanwhile operating costs are largely driven by costs related to employees' salaries and benefits which account for an average of 43.7 percent of the banking industry's operating costs and have been increasing overtime. Other notable costs components are rental expenses on premises and equipment, depreciation of premises and equipment, and utilities expenses. Employees' salaries and benefits costs are much higher for small banks at 44.4 percent of operating costs compared to 42.5 percent and 43.9 percent for medium size and large banks, respectively. 
The implications of these findings are that banks should intensify efforts towards improving operational efficiency targeted at reducing banks operating costs particularly employees' salaries and benefits as well as rental and depreciation expenses related on premises and equipment. In this, banks may consider to take advantage of ICT advancement in the country in services provision so as to cut on costs of "mortal and brick" as well as wages. Priority could be put on utilizing the growing agent banking framework, and digital banking technology. Prudent consolidation of small banks could as well help cut on operating costs, improving efficiency, and enhancing liquidity levels.

Meanwhile, measures need to be taken to reduce non-performing loans including through enhancing borrowers screening mechanisms aided by credit management frameworks at bank-level to reduce credit risk. Relatedly, strengthening of the regulatory and supervisory role is important, largely targeting on ensuring adequate liquidity in the banking system to square daily needs. Since SMR is not remunerated and so it is a tax on banks deposits, it is recommended to cautiously (consistent with the economy's absorption capacity) reduce SMR so as to enhance banks' lending ability thus reducing an upward pressure on lending rates. The EAC statutory reserve requirement convergence target is 5 percent by 2021, the target already attained by Burundi with a rate of 3 percent, Rwanda (5.0 percent), and Kenya (5.25 percent). Sustaining the macroeconomic stability through higher and sustainable economic growth and low and stable inflation could as well boost demand for credit and improve loan repayment capabilities, thus reducing credit risk.

This study has contributed to the literature on loanable funds and interest rate determination, largely focusing on determinants of bank lending rates and their relative importance. The study does not however claim to be exhaustive. Further empirical studies can be undertaken to evaluate in detail factors which influence operating costs at bank level, cost of funds (deposits rates), and non-performing loans.

\section{Acknowledgements and Disclaimer}

The authors sincerely appreciative the financial support provided by Bank of Tanzania in the course of carrying out this study. That notwithstanding, the views expressed in this paper are solely those of the authors and do not necessarily represent the opinion of Bank of Tanzania or any other institution.

\section{Conflicts of Interest}

The authors declare no conflicts of interest regarding the publication of this paper.

\section{References}

Ahokpossi, C. (2013). Determinants of Bank Interest Margins in Sub-Saharan Africa. Washington DC: International Monetary Fund. 
https://doi.org/10.5089/9781475551136.001

Aikael, J., Mugizi, F., \& Ndanshau, M. (2011). The Determinants of Interest Rate Spreads in Developing Countries: Evidence on Tanzania, 1991-2009. Working Paper No. 02/11, Dar Es Salaam: Department of Economics, University of Dar es Salaam. https://doi.org/10.2139/ssrn.1894008

Bank of Tanzania (BoT) (1996). Monetary Policy Statement, June. Dar es Salaam: Bank of Tanzania.

Bank of Tanzania (BoT) (2011). Tanzania Mainland's 50 Years of Independence: A Review of the Role and Functions of the Bank of Tanzania (1961-2011). Dar es Salaam: Bank of Tanzania.

Bank of Tanzania (BoT) (2016). 50th Anniversary of the Bank of Tanzania, Evolution of the Role and Functions of the Bank of Tanzania. Dar es Salaam: Bank of Tanzania.

Bank of Tanzania (BoT) (2018). Financial Stability Report, March 2018. Dar es Salaam: Bank of Tanzania.

Bhattarai, Y. R. (2015). Determinants of Lending Interest Rates of Nepalese Commercial Banks. Economic Journal of Development Issues, 19-20, 39-59.

Caplan, B. (2000). Rational Expectations. Virginia: Department of Economics, George Mason University.

Central Bank of Kenya (2018). Determinants of Lending Interest Rates and Interest Rate Spreads Using Bank Level Data in Kenya. Technical Meeting of EAC Monetary Affairs Committee, Arusha, 12-16 November 2018.

Chirwa, E. W., \& Mlachila, M. (2004). Financial Reforms and Interest Rate Spreads in the Commercial Banking System in Malawi. IMF Staff Papers, 51, 96-122.

Chodechai, S. (2004). Determinants of Bank Lending in Thailand: An Empirical Examination for the Years 1992-1996. New York: Frankfurt Am Main. Peter Lang.

Cihak, M. (2004). The Determinants of Lending Rates and Domestic Spreads in Croatia. In Republic of Croatia: Selected Issues and Statistical Appendix. IMF Country Report No. 04/251. https://doi.org/10.5089/9781451817294.002

Cihak, M., \& Podpiera, R. (2005). Bank Behavior in Developing Countries: Evidence from East Africa. IMF Working Paper Wp/05/129, Washington DC: International Monetary Fund. https://doi.org/10.5089/9781451861488.001

Cottrell, A., \& Jack, R. (2016). Gretl User's Guide: Gnu Regression, Econometrics and Time-Series Library, Department of Economics Wake Forest University and Lucchetti Dipartimento Di Economia Università Politecnica Delle Marche, July.

Demirguc-Kunt, A., \& Maksimovic, V. (1998). Law, Finance, and Firm Growth. Journal of Finance, 53, 2107-2137. https://doi.org/10.1111/0022-1082.00084

Friedman, B. M., \& Kuttner, K. N. (1991). Why Does the Paper-Bill Spread Predict Real Economic Activity? Cambridge, MA: National Bureau of Economic Research. https://doi.org/10.3386/w3879

Gambacorta, L. (2008). How Do Banks Set Interest Rates? European Economic Review, 52, 792-819. https://doi.org/10.1016/j.euroecorev.2007.06.022

Georgievska, L., Kabashi, R., Manova-Trajkovska, N. Mitreska, A., \& Vaskov, M. (2011). Determinants of Lending Interest Rates and Interest Rate Spreads. Bank of Greece: Special Conference Paper.

Greene, W. H. (2007). Econometric Analysis. Upper Saddle River, NJ: Pearson Prentice Hall.

Grenade, K. H. I. (2007). Determinants of Commercial Banks Interest Rate Spreads: Some 
Empirical Evidence from the Eastern Caribbean Currency Union. Eastern Caribbean Central Bank Staff Research Paper, WP/ 07/01.

Ho, T., \& Saunders, A. (1981). The Determinants of Bank Interest Margins: Theory and Empirical Evidence. Journal of Financial and Quantitative Analysis, 16, 581-600. https://doi.org/10.2307/2330377

Irungu, P. N. (2003). The Effect of Interest Rate Spread on Financial Performance of Commercial Banks in Kenya. Master's Thesis, Nairobi: University of Nairobi.

King, R. G., \& Levine, L. (1993a). Finance, Entrepreneurship, and Growth: Theory and Evidence. Journal of Monetary Economics, 32, 513-542. https://doi.org/10.1016/0304-3932(93)90028-E

King, R. G., \& Levine, R. (1993b). Finance and Growth: Schumpeter Might Be Right. Quarterly Journal of Economics, 108, 717-737. https://doi.org/10.2307/2118406

Klein, M. (1971). A Theory of the Banking Firm. Journal of Money Credit and Banking, 3, 205-218. https://doi.org/10.2307/1991279

Levine, R., \& Zervos, S. (1998). Stock Markets, Banks, and Economic Growth. American Economic Review, 88, 537-558. https://doi.org/10.1596/1813-9450-1690

Manamba, E. (2014). An Empirical Analysis of Interest Rate Spreads in Tanzania. Asian Journal of Research in Banking and Finance, 4, 244-269. https://doi.org/10.5958/2249-7323.2014.01425.4

Matemilola, B. T., Bany-Ariffin, A. N., \& Muhtar, F. E. (2015). The Impact of Monetary Policy on Bank Lending Rate in South Africa. Borsa Istanbul Review, 15, 53-59. https://doi.org/10.1016/j.bir.2014.09.003

Mbao, F. Z., Kapembwa, C., Mooka, O., Rasmussen, T., \& Sichalwe, J. (2014). Determinants of Bank Lending Rates in Zambia: A Balance Sheet Approach. Bank of Zambia, Working Paper, WP/02.

Mbowe, W. E. N. (2017). The Bank Lending Channel of Monetary Policy Transmission: A Dynamic Bank-Level Panel Data Analysis on Tanzania. Applied Economics and Finance, 4, 169-190. https://doi.org/10.11114/aef.v4i1.2097

Mbowe, W. E. N. (2018). Innovations Drive Financial Inclusion in Tanzania. African Review April, 22-23.

Monti, M. (1972). Deposit, Credit and Interest Rae Determination under Alternative Bank Objectives, In G. P. Szego, \& K. Shell (Eds.), Mathematical Methods in Investment and Finance. Amsterdam: North-Holland.

Nanjunga, T., Ntsosa, M. M., \& Motlaleng, G. (2016). Determinants of Commercial Banks' Interest Rate Spreads in Botswana. Botswana Journal of Economics, 14, 1-15.

National Bank of Rwanda (2018). Determinants of Lending Rates in Rwanda. Technical Meeting of EAC Monetary Affairs Committee, Arusha, 12-16 November 2018.

Olokoyo, F. O. (2011). Determinants of Commercial Banks' Lending Behavior in Nigeria. International Journal of Financial Research, 2, 61-62. https://doi.org/10.5430/ijfr.v2n2p61

Ongeri, G. M. (2012). The Effect of Macroeconomic Variables on the Financial Performance of Non-Bank Financial Institutions in Kenya. Kenya: Department of Finance and Accounting, University of Nairobi.

Onuonga, S. M. (2014). The Analysis of Profitability of Kenya's Top Six Commercial Banks: Internal Factor Analysis. American International Journal of Social Science, 3, 94-103.

Peng, W. S., Lai, K., Leung, F., \& Shu, C. (2002). Impact of Interest Rate Spread Rate Shocks on the Performance of Banking Sector. Hong Kong: Hong Kong Monetary Au- 
thority.

Rose, P. S. (2003). The Determinants of Interest Rates: Competing Ideas-PowerPoint PPT Presentation.

https://www.slideserve.com/thanos/the-determinants-of-interest-rates-competing-ideas

Samahiya, M., \& Kaakunga, E. (2011). Determinants of Commercial Bank Interest Rate Spread in Namibia: An Econometric Exploration. Botswana Journal of Economics, 12, $1-10$.

Siddique, M. A. (2012). Towards Determination of Interest Spread of Commercial Banks: Empirical Evidences from Pakistan. African Journal of Business Management, 6, 1851-1862.

Turnovsky, S. J. (1985). Short-Term and Long-Term Interest Rates in a Monetary Model of a Small Open Economy. Cambridge, MA: National Bureau of Economic Research. https://doi.org/10.3386/w1716

Were, M., \& Wambua, J. (2013). Assessing the Determinants of Interest Rate Spread of Commercial Banks in Kenya: An Empirical Investigation. Working Paper Series, WPS/01/13), Kenya Bankers Association (KBA), Centre for Research on Financial Markets and Policy. 


\section{Annex 1. Analysis Variables and Expected Signs}

\begin{tabular}{ll}
\hline Variable & Explanation \\
\hline Dependent & \\
Lending rate, (il) & Weighted average interest rate on banks loans. This is a price to a borrower.
\end{tabular}

\section{Independent variables}

Operating cost to total assets ratio, opcr

Cost of funds

Return on assets, ras

Default risk

Bank size

Bank rate (monetary policy effect)

Regulatory constraints

Market concentration

Inflation

Real GDP
Measures the cost of providing a loan unit by a bank and depends on the productivity of staff Positive and other operating costs. This is the key indicator of efficiency of commercial bank so that the lower the ratio, the higher the efficiency of the commercial bank.

Deposit interest rate, id is use to capture the cost of funds for a bank computed as weighted Positive average interest rate on retail deposits by each bank.

Increasing return on assets is likely to enhance bank's ability to cushion its assets against unexpected risks thus reducing lending rates.

It measures the effect on lending of a possibility of default due to a change in the financial health or condition of the borrower following normal or unexpected swings in the overall level of economic activity. Default rate on total loan and advances is proxied by non-performing loans to total loans ratio (nplr).

Computed as a ratio of bank's assets to industry total assets (siz), it captures the effect of bank's size on lending rate. As the size of a bank increases the likely that it will be able to cushion it's assets from falling following unexpected occurrences and can meet its loan obligations with less difficulties.

Another candidate variable in this area is liquid assets to total assets (lqr). Liquid assets comprise vault cash, treasury bills and bonds, bills receivable, clearing account balances and claims on banks.

Proxied by weighted average treasury bills rate (itbl) to capture the influence of monetary

Positive policy stance on lending rate. An increase in the central bank rate will signal policy tightening to commercial banks, thus lending rate or interest rate spreads are expected to increase.

Proxied by statutory minimum requirement (smr) to capture effects of regulatory

Positive requirements on lending rate. Another variable that could explain severity of regulation is provision for bad loans as a ratio of total loans (provr).

Market concentration (comp) approximates the level of competition in an industry, with lower market concentration resulting in higher competition thus pushing down spreads. $\mathrm{HHI}$ is used to measure degree of concentration, computed as the sum of squared market shares of all the firms in the market scaled from 0 to 10,000 .

Inflation (infl) is used as the cost of doing the business in the economy. High levels of inflation are expected to lead to high lending rates or interest rate spreads as it causes banks to charge a risk premium. Also, when the general prices of goods and services increase these lead to significant reduction in disposable income and the purchasing power of income earners. This ultimately leads to low level of savings and high rate of loan defaults, negatively affecting the financial performance of lenders.

Growth of economic activity (rgdp) can affect lending rates by: increasing the demand for loans leading to high lending rates; and by making projects more profitable which reduces defaults and increase the deposits that further reduce interest rate spreads.

Source: Authors compilation 
Annex 2. Industry-Wide Interest Rates Spread Decomposition

\begin{tabular}{cccccccccccc}
\hline \multirow{2}{*}{ Category } & \multicolumn{3}{c}{ Controbution in percentage points } & \multicolumn{3}{c}{ Contribution in percent } & Average \\
\cline { 2 - 9 } & $\mathbf{2 0 0 5 - 0 7}$ & $\mathbf{2 0 0 8 - 1 0}$ & $\mathbf{2 0 1 1 - 1 3}$ & $\mathbf{2 0 1 4 - 1 7}$ & $\mathbf{2 0 0 5 - 0 7}$ & $\mathbf{2 0 0 8 - 1 0}$ & $\mathbf{2 0 1 1 - 1 3}$ & $\mathbf{2 0 1 4 - 1 7}$ & $\mathbf{2 0 0 5 - 1 7}$ \\
\hline Interest rate spread & 9.3 & 8.3 & 7.6 & 7.4 & & & & & \\
Operating costs/assets & 2.6 & 2.1 & 2.5 & 2.3 & 28.0 & 25.3 & 32.9 & 31.1 & 29.3 \\
NPLs/gross loans & 1.5 & 2.4 & 2.0 & 2.2 & 16.1 & 28.9 & 26.3 & 29.7 & 25.3 \\
Provision for bad debts/gross loans & 0.8 & 0.6 & 0.3 & 0.7 & 8.6 & 7.2 & 3.9 & 9.5 & 7.3 \\
$\quad$ SMR ratio & 4.3 & 3.2 & 2.8 & 2.2 & 46.2 & 38.6 & 36.8 & 29.7 & 37.8 \\
\hline
\end{tabular}

Source: Authors' computation

\section{Annex 3. Operating Costs by Banks Category}

(a) Operating costs for small banks

\begin{tabular}{|c|c|c|c|c|c|c|c|c|c|c|c|c|}
\hline & 2006 & 2007 & 2008 & 2009 & 2010 & 2011 & 2012 & 2013 & 2014 & 2015 & 2016 & 2017 \\
\hline Employees salaries and benefits & 42.0 & 39.3 & 37.9 & 42.7 & 41.7 & 43.2 & 45.1 & 43.7 & 44.2 & 43.3 & 45.6 & 45.4 \\
\hline Rental expense on premises and equipment & 8.6 & 7.8 & 8.7 & 6.9 & 10.4 & 10.2 & 10.7 & 10.2 & 9.9 & 9.5 & 11.1 & 11.2 \\
\hline Depreciation-premises and equipment & 6.1 & 5.6 & 6.2 & 5.3 & 6.5 & 7.0 & 7.7 & 6.9 & 6.0 & 4.5 & 4.3 & 4.5 \\
\hline Insurance & 3.0 & 2.7 & 2.7 & 3.0 & 2.9 & 2.7 & 2.4 & 2.4 & 2.3 & 2.2 & 2.3 & 2.5 \\
\hline Amortization-leasehold rights and improvements & 0.3 & 0.4 & 1.7 & 1.4 & 1.3 & 1.7 & 1.3 & 1.5 & 2.1 & 2.0 & 2.2 & 2.4 \\
\hline Utilities expenses & 4.8 & 4.6 & 4.1 & 5.7 & 3.8 & 3.0 & 2.8 & 2.8 & 3.5 & 2.6 & 2.7 & 2.0 \\
\hline Taxes and license fees & 0.7 & 0.2 & 0.8 & 0.3 & 0.3 & 0.5 & 0.3 & 0.5 & 0.6 & 0.8 & 0.8 & 1.2 \\
\hline Management fees & 0.5 & 0.4 & 1.4 & 0.0 & 0.6 & 4.4 & 2.4 & 4.6 & 4.2 & 5.9 & 1.9 & 1.2 \\
\hline Other professional fees & 0.9 & 1.5 & 1.2 & 1.2 & 1.3 & 2.7 & 2.1 & 1.6 & 1.9 & 2.0 & 1.9 & 1.0 \\
\hline Auditors fees & 0.8 & 0.9 & 0.7 & 0.8 & 0.8 & 0.8 & 0.7 & 0.6 & 0.5 & 0.6 & 0.8 & 0.9 \\
\hline Foreclosure and litigation expenses & 0.1 & 0.2 & 0.4 & 0.5 & 0.1 & 0.0 & 0.2 & 0.1 & 0.0 & 0.2 & 0.4 & 0.6 \\
\hline Others & 32.2 & 36.4 & 34.1 & 32.3 & 30.3 & 23.8 & 24.7 & 25.1 & 24.7 & 26.3 & 26.0 & 27.4 \\
\hline Total & 100.0 & 100.0 & 100.0 & 100.0 & 100.0 & 100.0 & 100.3 & 100.0 & 100.0 & 100.0 & 100.0 & 100.0 \\
\hline
\end{tabular}

Source: Authors' computation. Note: Small banks category covers all banks with assets share equal to or less than one percent of the banking industry assets.

(b) Operating costs for medium size banks

\begin{tabular}{|c|c|c|c|c|c|c|c|c|c|c|c|c|}
\hline & 2006 & 2007 & 2008 & 2009 & 2010 & 2011 & 2012 & 2013 & 2014 & 2015 & 2016 & 2017 \\
\hline Employees salaries and benefits & 39.9 & 41.6 & 42.8 & 46.7 & 44.3 & 44.2 & 43.6 & 42.8 & 43.7 & 42.4 & 41.6 & 41.8 \\
\hline Rental expense on premises and equipment & 5.6 & 6.1 & 5.5 & 7.6 & 7.4 & 8.7 & 8.5 & 8.8 & 8.4 & 9.5 & 10.3 & 9.6 \\
\hline Depreciation-premises and equipment & 7.0 & 6.0 & 6.3 & 8.5 & 8.0 & 7.5 & 6.8 & 6.6 & 5.9 & 5.6 & 6.0 & 6.6 \\
\hline Utilities expenses & 4.5 & 2.3 & 3.2 & 3.0 & 2.3 & 2.1 & 2.6 & 2.6 & 2.4 & 2.3 & 2.9 & 5.2 \\
\hline Insurance & 1.2 & 1.1 & 1.0 & 1.3 & 1.5 & 2.0 & 2.1 & 2.3 & 2.6 & 2.6 & 2.6 & 2.3 \\
\hline Taxes and license fees & 0.1 & 0.4 & 0.0 & 0.0 & 0.0 & 0.6 & 0.6 & 0.4 & 0.9 & 1.0 & 1.7 & 2.1 \\
\hline Other professional fees & 1.4 & 1.2 & 0.7 & 1.4 & 1.4 & 1.2 & 1.2 & 1.5 & 2.4 & 1.7 & 1.7 & 1.5 \\
\hline Amortization-leasehold rights and improvements & 0.1 & 0.1 & 0.1 & 0.3 & 0.4 & 0.4 & 0.6 & 0.9 & 1.0 & 0.9 & 0.9 & 1.1 \\
\hline Auditors fees & 0.8 & 0.6 & 0.5 & 0.5 & 0.6 & 0.5 & 0.5 & 0.5 & 0.6 & 0.5 & 0.6 & 0.7 \\
\hline
\end{tabular}




\section{Continued}

\begin{tabular}{|c|c|c|c|c|c|c|c|c|c|c|c|c|}
\hline Management fees & 0.4 & 4.9 & 6.4 & -6.7 & -1.8 & 0.6 & 0.4 & 0.6 & 0.4 & 0.4 & 0.3 & 0.4 \\
\hline Foreclosure and litigation expenses & 0.0 & 0.0 & 0.0 & 0.0 & 0.0 & 0.0 & 0.0 & 0.1 & 0.0 & 0.1 & 0.2 & 0.2 \\
\hline Others & 39.2 & 35.7 & 33.3 & 37.1 & 35.9 & 32.2 & 33.2 & 33.0 & 31.8 & 33.0 & 31.3 & 28.6 \\
\hline Total & 100.0 & 100.0 & 100.0 & 100.0 & 100.0 & 100.0 & 100.0 & 100.0 & 100.0 & 100.0 & 100.0 & 100.0 \\
\hline
\end{tabular}

Source: Authors' computation. Note: Medium size banks category includes all banks with assets share greater than one percent but less than four percent of the banking industry assets.

(c) Operating costs for large banks

\begin{tabular}{|c|c|c|c|c|c|c|c|c|c|c|c|c|}
\hline & 2006 & 2007 & 2008 & 2009 & 2010 & 2011 & 2012 & 2013 & 2014 & 2015 & 2016 & 2017 \\
\hline Employees salaries and benefits & 39.9 & 40.7 & 40.5 & 41.5 & 38.9 & 40.2 & 41.1 & 42.9 & 43.8 & 43.8 & 44.3 & 44.8 \\
\hline Depreciation-premises and equipment & 5.7 & 6.1 & 6.6 & 7.1 & 7.3 & 7.9 & 9.6 & 7.7 & 7.3 & 6.4 & 6.7 & 7.3 \\
\hline Rental expense on premises and equipment & 4.6 & 4.6 & 4.5 & 4.8 & 4.5 & 4.9 & 4.4 & 4.3 & 4.3 & 4.7 & 5.1 & 5.0 \\
\hline Taxes and license fees & 2.4 & 1.7 & 1.4 & 1.8 & 2.8 & 2.4 & 2.7 & 1.9 & 2.8 & 3.2 & 3.8 & 2.8 \\
\hline Utilities expenses & 3.6 & 2.9 & 3.1 & 4.1 & 3.4 & 3.5 & 3.9 & 3.7 & 3.4 & 2.8 & 2.7 & 2.6 \\
\hline Insurance & 2.5 & 2.5 & 2.5 & 2.5 & 2.5 & 3.0 & 2.4 & 2.4 & 2.4 & 2.3 & 2.4 & 2.5 \\
\hline Other professional fees & 1.4 & 2.6 & 0.6 & 0.6 & 1.2 & 1.7 & 2.2 & 1.1 & 1.5 & 1.5 & 1.5 & 1.5 \\
\hline Amortization-leasehold rights and improvements & 0.6 & 0.6 & 0.6 & 0.5 & 0.6 & 0.7 & 0.7 & 0.7 & 0.7 & 0.7 & 0.8 & 1.0 \\
\hline Management fees & 0.9 & 0.5 & 0.6 & 1.5 & 1.5 & 1.3 & 1.3 & 0.9 & 0.9 & 1.0 & -0.7 & 0.6 \\
\hline Auditors fees & 0.6 & 0.4 & 0.4 & 0.4 & 0.5 & 0.3 & 0.4 & 0.3 & 0.3 & 0.3 & 0.3 & 0.3 \\
\hline Foreclosure and litigation expenses & 0.4 & 0.3 & 0.4 & 0.3 & 0.4 & 0.4 & 0.3 & 0.3 & 0.3 & 0.3 & 0.3 & 0.2 \\
\hline Others & 37.4 & 37.1 & 38.9 & 34.9 & 36.5 & 33.7 & 31.0 & 33.9 & 32.2 & 33.0 & 32.7 & 31.5 \\
\hline Total & 100.0 & 100.0 & 100.0 & 100.0 & 100.0 & 100.0 & 100.0 & 100.0 & 100.0 & 100.0 & 100.0 & 100.0 \\
\hline
\end{tabular}

Source: Authors' computation. Note: Large banks category comprises all banks with assets share greater than or equal to four percent of the banking industry assets.

(d) Operating costs for locally owned banks

\begin{tabular}{|c|c|c|c|c|c|c|c|c|c|c|c|c|}
\hline & 2006 & 2007 & 2008 & 2009 & 2010 & 2011 & 2012 & 2013 & 2014 & 2015 & 2016 & 2017 \\
\hline Employees salaries and benefits & 42.0 & 41.1 & 42.2 & 43.0 & 40.6 & 42.1 & 42.6 & 44.2 & 44.3 & 44.8 & 43.5 & 43.7 \\
\hline Depreciation-premises and equipment & 6.5 & 7.0 & 7.4 & 8.2 & 8.0 & 7.9 & 9.7 & 7.5 & 7.0 & 6.4 & 6.7 & 7.6 \\
\hline Rental Expense on premises and equipment & 3.0 & 3.2 & 3.3 & 3.6 & 3.9 & 4.2 & 3.9 & 4.1 & 4.2 & 4.9 & 5.2 & 5.5 \\
\hline Utilities expenses & 4.9 & 3.8 & 4.1 & 4.6 & 4.4 & 4.6 & 4.8 & 4.5 & 4.0 & 3.3 & 3.2 & 3.1 \\
\hline Insurance & 2.1 & 2.3 & 2.6 & 2.7 & 2.6 & 2.9 & 2.7 & 2.8 & 2.7 & 2.6 & 2.8 & 2.8 \\
\hline Taxes and license fees & 1.2 & 1.5 & 0.9 & 1.4 & 1.8 & 1.2 & 1.3 & 1.2 & 2.6 & 2.7 & 3.0 & 2.1 \\
\hline Other professional fees & 1.1 & 1.4 & 0.8 & 0.9 & 1.3 & 1.9 & 1.5 & 1.4 & 1.5 & 1.8 & 1.6 & 1.6 \\
\hline Amortization-leasehold rights and improvements & 1.0 & 0.9 & 0.9 & 0.8 & 0.9 & 1.1 & 1.0 & 1.1 & 1.1 & 1.0 & 1.2 & 1.4 \\
\hline Management fees & 1.6 & 0.8 & 1.0 & 1.5 & 1.3 & 1.4 & 1.1 & 0.7 & 0.7 & 0.8 & 0.5 & 0.3 \\
\hline Auditors fees & 0.5 & 0.4 & 0.4 & 0.4 & 0.4 & 0.3 & 0.3 & 0.3 & 0.2 & 0.3 & 0.3 & 0.3 \\
\hline Foreclosure and litigation expenses & 0.2 & 0.2 & 0.2 & 0.2 & 0.2 & 0.1 & 0.2 & 0.2 & 0.3 & 0.2 & 0.2 & 0.1 \\
\hline Supervision and Inspection Fees/BOT Charges/Penalties & 0.0 & 0.0 & 0.0 & 0.0 & 0.0 & 0.0 & 0.0 & 0.0 & 0.2 & 0.0 & 0.0 & 0.0 \\
\hline Others & 36.1 & 37.4 & 36.2 & 32.8 & 34.7 & 32.4 & 30.9 & 32.0 & 31.3 & 31.2 & 31.9 & 31.5 \\
\hline Total & 100.0 & 100.0 & 100.0 & 100.0 & 100.0 & 100.0 & 100.0 & 100.0 & 100.0 & 100.0 & 100.0 & 100.0 \\
\hline
\end{tabular}

Source: Authors' computation. 
W. E. Mbowe et al.

(e) Operating costs for foreign owned banks

\begin{tabular}{|c|c|c|c|c|c|c|c|c|c|c|c|c|}
\hline & 2006 & 2007 & 2008 & 2009 & 2010 & 2011 & 2012 & 2013 & 2014 & 2015 & 2016 & 2017 \\
\hline Employees salaries and benefits & 38.4 & 40.5 & 40.0 & 42.6 & 40.3 & 41.0 & 41.8 & 41.8 & 43.5 & 42.0 & 44.4 & 44.9 \\
\hline Rental Expense on premises and equipment & 6.6 & 6.7 & 6.4 & 7.3 & 7.2 & 8.1 & 8.3 & 8.1 & 7.9 & 8.3 & 9.6 & 8.9 \\
\hline Depreciation-premises and equipment & 5.6 & 5.3 & 5.8 & 6.5 & 6.9 & 7.5 & 7.8 & 7.2 & 6.5 & 5.5 & 5.6 & 5.6 \\
\hline Utilities expenses & 3.0 & 1.9 & 2.4 & 3.5 & 2.2 & 1.9 & 2.2 & 2.2 & 2.3 & 2.1 & 2.2 & 3.1 \\
\hline Taxes and license fees & 2.3 & 1.3 & 1.1 & 1.1 & 2.0 & 2.3 & 2.5 & 1.5 & 1.5 & 1.9 & 2.6 & 2.7 \\
\hline Insurance & 2.3 & 2.2 & 1.7 & 1.9 & 2.1 & 2.6 & 2.0 & 2.0 & 2.1 & 2.1 & 2.1 & 2.0 \\
\hline Other professional fees & 1.7 & 3.0 & 0.5 & 0.8 & 1.2 & 1.5 & 2.3 & 1.1 & 2.1 & 1.4 & 1.7 & 1.1 \\
\hline Management fees & 0.2 & 2.0 & 3.0 & -2.1 & 0.1 & 1.6 & 1.2 & 1.9 & 1.9 & 2.5 & -0.7 & 1.1 \\
\hline Amortization-leasehold rights and improvements & 0.2 & 0.2 & 0.3 & 0.4 & 0.4 & 0.5 & 0.5 & 0.7 & 0.9 & 0.8 & 0.9 & 1.0 \\
\hline Auditors fees & 0.7 & 0.5 & 0.5 & 0.5 & 0.6 & 0.5 & 0.6 & 0.5 & 0.6 & 0.5 & 0.6 & 0.7 \\
\hline Foreclosure and litigation expenses & 0.3 & 0.3 & 0.4 & 0.4 & 0.4 & 0.4 & 0.3 & 0.2 & 0.1 & 0.2 & 0.3 & 0.4 \\
\hline Others & 38.6 & 36.1 & 37.9 & 37.2 & 36.7 & 32.2 & 30.5 & 32.9 & 30.6 & 32.7 & 30.7 & 28.6 \\
\hline Total & 100.0 & 100.0 & 100.0 & 100.0 & 100.0 & 100.0 & 100.0 & 100.0 & 100.0 & 100.0 & 100.0 & 100.0 \\
\hline
\end{tabular}

Source: Authors' computation

Annex 4. Econometric Results across Different Categories of Banks

(a) Local banks

Dependent variable: Lending interest rate

Average values

of significant

coefficients

Model 2: Local banks

\begin{tabular}{|c|c|c|c|c|c|c|c|}
\hline $\begin{array}{l}\text { Independent } \\
\text { variable }\end{array}$ & $\begin{array}{c}\text { Weighted Least } \\
\text { Squares }\end{array}$ & & Fixed effect & & Random effect & & \\
\hline & No Lag & $1 \mathrm{Lag}$ & No Lag & $1 \mathrm{Lag}$ & No Lag & $1 \mathrm{Lag}$ & \\
\hline const & $17.871^{\star \star}$ & -17.650 & $24.892^{\star *}$ & $-88.087^{\star}$ & $20.458^{*}$ & -35.670 & \\
\hline il & & $0.282^{\star * *}$ & & -0.202 & & 0.262 & 0.282 \\
\hline id & -0.089 & 0.042 & $-0.249^{* *}$ & 0.303 & -0.199 & 0.279 & -0.249 \\
\hline ras & -0.057 & 0.159 & 0.109 & 0.006 & -0.042 & -0.064 & \\
\hline opcr & 0.059 & -0.020 & 0.143 & 0.102 & 0.065 & -0.076 & \\
\hline nplr & -0.035 & 0.008 & $-0.107^{\star}$ & 0.116 & $-0.094^{* * *}$ & -0.023 & -0.101 \\
\hline siz & -0.018 & $0.151^{* *}$ & -0.066 & $0.405^{\star * *}$ & -0.054 & $0.192^{*}$ & 0.249 \\
\hline liqr & 0.035 & $0.169^{\star * *}$ & 0.020 & 0.129 & 0.038 & $0.231^{* *}$ & 0.200 \\
\hline provr & -0.110 & 0.165 & 0.043 & 0.382 & -0.017 & 0.159 & \\
\hline smr & $-0.815^{*}$ & $1.306^{\star * *}$ & -0.751 & $2.304^{* *}$ & -0.686 & $2.197^{\star \star *}$ & 1.248 \\
\hline rgdp & -0.043 & 0.702 & -1.007 & 3.685 & -0.461 & 2.013 & \\
\hline infl & -0.038 & 0.053 & $-0.360^{\star *}$ & 0.360 & -0.163 & 0.146 & -0.360 \\
\hline itbl & -0.063 & $0.325^{* *}$ & -0.099 & 0.093 & -0.026 & 0.117 & 0.325 \\
\hline HHI_AS & 0.007 & 0.004 & $0.011^{*}$ & 0.052 & 0.008 & 0.004 & 0.011 \\
\hline Adj $R^{2}$ & 0.068 & 0.727 & & & & & \\
\hline
\end{tabular}




\section{Continued}

\begin{tabular}{|c|c|c|c|c|c|c|}
\hline F-stastic & $1.723^{*}$ & $11.263^{\star * *}$ & $\mathrm{~F}(12,28)=3.865^{\star * *}$ & $\begin{array}{c}\mathrm{F}(13,52)= \\
2.465^{\star *}\end{array}$ & & \\
\hline $\begin{array}{l}\text { Null } \\
\text { hypothesis }\end{array}$ & & & $\begin{array}{l}\text { Groups common } \\
\text { intercept: Welch } \mathrm{F}(28, \\
27.1)=10.6 ; p \text {-value }= \\
0.000\end{array}$ & $\begin{array}{l}\text { Groups } \\
\text { common } \\
\text { intercept: } \\
\text { Welch } \mathrm{F}(27, \\
20.7)=4.978 ; \\
p \text {-value }= \\
0.000\end{array}$ & $\begin{array}{l}\text { 1) Breusch-Pagan } \\
\text { test: Unit-specific } \\
\text { error variance }=0 \text {; } \\
\text { Chi-square }(1)= \\
3.514, p \text {-value } 0.060 \text {. } \\
\text { Hausman test: GLS } \\
\text { estimates are } \\
\text { consistent; } \\
\text { Chi-square }(12)= \\
28.16, p \text {-value } 0.005\end{array}$ & $\begin{array}{l}\text { 1) Breusch-Pagan test: } \\
\text { Unit-specific error variance }=0 \text {; } \\
\text { Chi-square }(1)=0.358 ; p \text {-value } \\
0.0 .549 . \text { Hausman test: GLS } \\
\text { estimates are consistent; } \\
\text { Chi-square }(13)=25.239, p \text {-value } \\
0.021\end{array}$ \\
\hline
\end{tabular}

Source: Authors' computation. Note: ${ }^{* *(* *) *}$ means significant at $1 \%(5 \%) 10 \%$. Robust (HAC) standard errors were used in weighted least squares and fixed effect estimations.

(b) Foreign banks

\begin{tabular}{|c|c|c|c|c|c|c|c|}
\hline \multicolumn{7}{|c|}{ Dependent variable: Lending interest rate } & \multirow{4}{*}{$\begin{array}{c}\text { Average } \\
\text { values of } \\
\text { significant } \\
\text { coefficients }\end{array}$} \\
\hline \multicolumn{7}{|c|}{ Model 3: Foreign banks } & \\
\hline \multirow{2}{*}{$\begin{array}{c}\text { Independent } \\
\text { variable }\end{array}$} & \multicolumn{2}{|c|}{ Weighted Least Squares } & \multicolumn{2}{|c|}{ Fixed effect } & \multicolumn{2}{|c|}{ Random effect } & \\
\hline & No Lag & $1 \mathrm{Lag}$ & No Lag & $1 \mathrm{Lag}$ & No Lag & $1 \mathrm{Lag}$ & \\
\hline const & 8.048 & -4.211 & 13.095 & -5.519 & 14.033 & -0.330 & \\
\hline il & & -0.013 & & -0.038 & & -0.010 & \\
\hline id & $0.534^{* * *}$ & $0.256^{*}$ & $0.583^{* * *}$ & 0.203 & $0.564^{* * *}$ & 0.124 & 0.484 \\
\hline ras & $0.220^{* *}$ & 0.084 & 0.233 & 0.106 & $0.244^{* *}$ & 0.124 & 0.232 \\
\hline opcr & $0.652^{* * *}$ & $0.292^{\star * *}$ & $0.746^{* * *}$ & $0.262^{\star *}$ & $0.760^{* * *}$ & $0.275^{\star *}$ & 0.498 \\
\hline nplr & 0.034 & $-0.078^{\star *}$ & 0.042 & -0.046 & 0.041 & $-0.070^{*}$ & -0.074 \\
\hline $\operatorname{siz}$ & 0.007 & -0.095 & -0.028 & -0.159 & -0.025 & -0.151 & \\
\hline liqr & $-0.083^{\star * \star}$ & -0.051 & $-0.105^{\star * *}$ & -0.048 & $-0.104^{\star * *}$ & -0.052 & -0.097 \\
\hline provr & $-0.050^{\star \star}$ & $-0.078^{\star * *}$ & $-0.056^{\star * *}$ & $-0.068^{\star * *}$ & $-0.053^{\star}$ & $-0.070^{\star * *}$ & \\
\hline $\mathrm{smr}$ & $-1.608^{\star * *}$ & -0.028 & $-1.956^{\star * *}$ & -0.033 & $-1.987^{\star * *}$ & 0.039 & -1.850 \\
\hline rgdp & 0.035 & -0.493 & -0.202 & -0.476 & -0.173 & -0.663 & \\
\hline infl & -0.134 & -0.225 & -0.167 & -0.238 & -0.155 & -0.242 & \\
\hline itbl & 0.096 & -0.185 & 0.113 & -0.060 & 0.103 & -0.171 & \\
\hline HHI_AS & $0.015^{* * *}$ & $0.026^{* * *}$ & $0.014^{* *}$ & $0.027^{* * *}$ & $0.013^{* *}$ & $0.024^{* * *}$ & 0.020 \\
\hline $\operatorname{Adj} R^{2}$ & 0.387 & 0.284 & & & & & \\
\hline F-stastic & $13.420^{* * *}$ & $5.214^{* * *}$ & $\begin{array}{c}\mathrm{F}(12,29)= \\
10.222^{* * *}\end{array}$ & $\begin{array}{c}\mathrm{F}(13,29)= \\
5.213^{\star \star *}\end{array}$ & & & \\
\hline $\begin{array}{l}\text { Null } \\
\text { hypothesis }\end{array}$ & & & $\begin{array}{l}\text { Groups } \\
\text { common } \\
\text { intercept: } \\
\text { Welch } \mathrm{F}(29 \\
27.2)=0.556 \\
p \text {-value }=0.959\end{array}$ & $\begin{array}{l}\text { Groups } \\
\text { common } \\
\text { intercept: } \\
\text { Welch } \mathrm{F}(29 \\
33.2)=0.909 ; \\
p \text {-value }= \\
0.599\end{array}$ & $\begin{array}{l}\text { 1) Breusch-Pagan test: } \\
\text { Unit-specific error variance } \\
=0 \text {; Chi-square }(1)=2.146 \text {, } \\
p \text {-value } 0.142 . \text { Hausman } \\
\text { test: GLS estimates are } \\
\text { consistent; Chi-square }(12) \\
=1.408, p \text {-value } 0.999\end{array}$ & $\begin{array}{l}\text { 1) Breusch-Pagan test: } \\
\text { Unit-specific error variance } \\
=0 \text {; Chi-square }(1)=1.580 \text {; } \\
p \text {-value } 0.0 .208 \text {; Hausman } \\
\text { test: GLS estimates are } \\
\text { consistent; Chi-square }(13)= \\
12.898, p \text {-value } 0.455\end{array}$ & \\
\hline
\end{tabular}

Source: Authors' computation. Note: ${ }^{* * *(* *)}$ means significant at $1 \%(5 \%) 10 \%$. Robust (HAC) standard errors were used in weighted least squares and fixed effect estimations. 
(c) Small banks

\begin{tabular}{|c|c|c|c|c|c|c|c|}
\hline \multicolumn{7}{|c|}{ Dependent variable: Lending interest rate } & \multirow{4}{*}{$\begin{array}{c}\text { Average } \\
\text { values of } \\
\text { significant } \\
\text { coefficients }\end{array}$} \\
\hline \multicolumn{7}{|c|}{ Model 4: Small banks } & \\
\hline \multirow{2}{*}{$\begin{array}{l}\text { Independent } \\
\text { variable }\end{array}$} & \multicolumn{2}{|c|}{ Weighted Least Squares } & \multicolumn{2}{|c|}{ Fixed effect } & \multicolumn{2}{|c|}{ Random effect } & \\
\hline & No Lag & $1 \mathrm{Lag}$ & No Lag & $1 \mathrm{Lag}$ & No Lag & $1 \mathrm{Lag}$ & \\
\hline const & $20.127^{* *}$ & $30.094^{*}$ & $42.013^{* *}$ & -40.791 & $29.771^{*}$ & 9.514 & \\
\hline il & & 0.099 & & 0.138 & & 0.154 & \\
\hline id & 0.019 & $0.581^{* *}$ & -0.233 & -0.444 & 0.021 & 0.732 & 0.581 \\
\hline ras & 0.123 & -0.428 & 0.073 & $-1.228^{\star *}$ & 0.181 & -0.716 & 0.228 \\
\hline opcr & $0.315^{* * *}$ & $-0.360^{* *}$ & $0.237^{\star}$ & -0.297 & $0.335^{\star * *}$ & -0.353 & 0.312 \\
\hline nplr & $-0.081^{\star * *}$ & 0.064 & $-0.137^{* * *}$ & $0.445^{*}$ & $-0.109^{* *}$ & 0.184 & 0.070 \\
\hline siz & -0.931 & $-11.400^{\star * \star}$ & 0.067 & 2.384 & -1.778 & $-9.747^{\star}$ & \\
\hline liqr & -0.035 & $-0.239^{* * *}$ & -0.058 & -0.211 & -0.040 & $-0.248^{*}$ & -0.239 \\
\hline provr & -0.032 & $-0.420^{* *}$ & -0.030 & $-2.020^{\star *}$ & -0.024 & $-0.588^{\star}$ & -1.009 \\
\hline $\mathrm{smr}$ & $-1.220^{\star * *}$ & 1.273 & $-1.832^{*}$ & 1.704 & $-2.015^{\star * *}$ & 3.018 & -1.850 \\
\hline rgdp & 0.541 & $-1.036^{*}$ & -1.187 & 4.168 & -0.175 & -0.707 & -1.036 \\
\hline infl & -0.164 & 0.099 & $-0.451^{\star}$ & 0.718 & -0.175 & 0.226 & -0.451 \\
\hline itbl & 0.100 & -0.111 & 0.080 & -0.118 & 0.090 & 0.111 & \\
\hline HHI_AS & 0.003 & -0.009 & 0.005 & 0.020 & 0.007 & -0.014 & 0.020 \\
\hline Adj $R^{2}$ & 0.309 & 0.473 & & & & & \\
\hline F-stastic & $6.749^{* * *}$ & $5.628^{* * *}$ & $\begin{array}{c}\mathrm{F}(12,39)= \\
2.764^{* * *}\end{array}$ & $\begin{array}{c}\mathrm{F}(13,37)= \\
6.082^{* * *}\end{array}$ & & & \\
\hline $\begin{array}{l}\text { Null } \\
\text { hypothesis }\end{array}$ & & & $\begin{array}{l}\text { Groups } \\
\text { common } \\
\text { intercept: } \\
\text { Welch } \mathrm{F}(39 \\
33.4)=0.794 \\
p \text {-value }= \\
0.756\end{array}$ & $\begin{array}{l}\text { Groups } \\
\text { common } \\
\text { intercept: } \\
\text { Welch F( } 37, \\
24.8)=1.125 ; \\
p \text {-value }= \\
0.384\end{array}$ & $\begin{array}{l}\text { 1) Breusch-Pagan test: } \\
\text { Unit-specific error variance } \\
=0 \text {; Chi-square }(1)=0.083 \text {, } \\
p \text {-value } 0.772 \text {. Hausman } \\
\text { test: GLS estimates are } \\
\text { consistent; Chi-square }(12) \\
=26.392, p \text {-value } 0.0 .009\end{array}$ & $\begin{array}{l}\text { 1) Breusch-Pagan test: } \\
\text { Unit-specific error variance } \\
=0 \text {; Chi-square }(1)=1.383 \\
p \text {-value } 0.239 ; \text { Hausman } \\
\text { test: GLS estimates are } \\
\text { consistent; Chi-square }(13) \\
=58.712, p \text {-value } 0.000\end{array}$ & \\
\hline
\end{tabular}

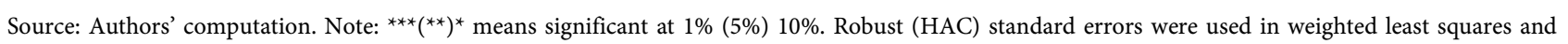
fixed effect estimations.

(d) Medium size banks

Dependent variable: Lending interest rate

\begin{tabular}{|c|c|c|c|c|c|}
\hline \multicolumn{5}{|c|}{ Model 5: Mediun size banks } & \multirow{3}{*}{$\begin{array}{c}\text { Average } \\
\text { values of } \\
\text { significant } \\
\text { coefficients }\end{array}$} \\
\hline \multirow{2}{*}{$\begin{array}{l}\text { Independent } \\
\text { variable }\end{array}$} & \multicolumn{2}{|c|}{ Weighted Least Squares } & \multicolumn{2}{|c|}{ Fixed effect } & \\
\hline & No Lag & 1 Lag & No Lag & $1 \mathrm{Lag}$ & \\
\hline const & -11.5933 & $37.418^{* * *}$ & -4.7781 & $35.098^{*}$ & \\
\hline il & & $-0.190^{*}$ & & -0.181 & -0.190 \\
\hline id & $0.434^{* * *}$ & 0.350 & $0.528^{* *}$ & $0.438^{*}$ & 0.467 \\
\hline ras & $0.641^{* * *}$ & 0.157 & 0.801 & 0.116 & 0.641 \\
\hline opcr & $1.651^{* * *}$ & -0.548 & $1.588^{\star * *}$ & -0.522 & 1.620 \\
\hline
\end{tabular}


W. E. Mbowe et al.

\section{Continued}

\begin{tabular}{|c|c|c|c|c|c|}
\hline nplr & 0.054 & -0.031 & 0.061 & -0.036 & \\
\hline $\operatorname{siz}$ & $2.378^{* * *}$ & $-3.410^{* * *}$ & $2.016^{*}$ & $-3.851^{*}$ & -0.717 \\
\hline liqr & -0.024 & $-0.095^{\star}$ & -0.076 & -0.097 & -0.095 \\
\hline provr & $0.301^{*}$ & 0.027 & 0.331 & -0.024 & \\
\hline smr & $-0.830^{*}$ & 0.056 & $-1.229^{\star *}$ & -0.303 & -1.030 \\
\hline rgdp & -0.645 & -0.505 & -0.543 & -0.298 & \\
\hline infl & -0.147 & -0.239 & -0.139 & -0.106 & \\
\hline itbl & -0.015 & $-0.483^{\star * *}$ & -0.056 & $-0.421^{\star * *}$ & -0.452 \\
\hline HHI_AS & $0.024^{* * *}$ & -0.002 & $0.021^{* *}$ & 0.001 & 0.023 \\
\hline Adj $R^{2}$ & 0.307 & 0.143 & & & \\
\hline F-stastic & $4.930^{* * *}$ & $2.005^{\star *}$ & $\mathrm{~F}(12,11)=1.789^{* * *}$ & & \\
\hline Null hypothesis & & & $\begin{array}{l}\text { Groups common intercept: } \\
\text { Welch } \mathrm{F}(11,36.8)=0.574 \\
p \text {-value }=0.836\end{array}$ & $\begin{array}{l}\text { Groups common intercept: } \\
\text { Welch } \mathrm{F}(11,24.8)=0.796 ; \\
p \text {-value }=0.641\end{array}$ & \\
\hline
\end{tabular}

Source: Authors' computation. Note: ${ }^{* * *}(* *)^{*}$ means significant at $1 \%(5 \%) 10 \%$. Robust (HAC) standard errors were used in weighted least squares and fixed effect estimations.

(e) Large banks

\begin{tabular}{|c|c|c|c|c|c|}
\hline \multicolumn{5}{|c|}{ Dependent variable: Lending interest rate } & \multirow{4}{*}{$\begin{array}{l}\text { Average } \\
\text { values of } \\
\text { significant } \\
\text { coefficient }\end{array}$} \\
\hline \multirow{3}{*}{$\begin{array}{c}\text { Independent } \\
\text { variable }\end{array}$} & \multicolumn{4}{|c|}{ Model 6: Large banks } & \\
\hline & \multicolumn{2}{|c|}{ Weighted Least Squares } & \multicolumn{2}{|c|}{ Fixed effect } & \\
\hline & No Lag & $1 \mathrm{Lag}$ & No Lag & $1 \mathrm{Lag}$ & \\
\hline const & -8.176 & $37.394^{\star * *}$ & -7.120 & $44.615^{\star * *}$ & \\
\hline il & & $0.277^{\star *}$ & & $0.336^{\star *}$ & 0.307 \\
\hline id & 0.220 & $-0.578^{* * *}$ & $0.214^{* *}$ & $-0.664^{* * *}$ & -0.343 \\
\hline ras & -0.404 & 0.353 & -0.348 & 0.151 & 0.641 \\
\hline opcr & $0.923^{* * *}$ & -0.206 & $0.963^{\star * *}$ & -0.458 & 0.943 \\
\hline nplr & 0.123 & 0.156 & 0.145 & $0.232^{* *}$ & 0.232 \\
\hline $\operatorname{siz}$ & $0.222^{\star *}$ & -0.015 & $0.223^{\star * *}$ & 0.009 & 0.223 \\
\hline liqr & $0.117^{\star \star \star}$ & -0.069 & $0.117^{\star \star \star}$ & -0.065 & 0.117 \\
\hline provr & -0.049 & 0.024 & -0.101 & -0.164 & \\
\hline $\mathrm{smr}$ & $-1.010^{\star}$ & 0.680 & $-0.993^{*}$ & 0.837 & -1.002 \\
\hline rgdp & -0.082 & $-1.895^{\star}$ & -0.174 & $-2.447^{\star \star *}$ & -2.171 \\
\hline infl & 0.028 & -0.335 & 0.033 & $-0.364^{\star \star}$ & -0.364 \\
\hline itbl & 0.091 & $-0.257^{*}$ & 0.086 & -0.246 & -0.257 \\
\hline HHI_AS & $0.020^{* * *}$ & -0.010 & $0.019^{\star}$ & $-0.013^{\star \star}$ & 0.009 \\
\hline Adj $R^{2}$ & 0.419 & 0.188 & & & \\
\hline F-stastic & $6.535^{\star * *}$ & $2.496^{* * *}$ & & & \\
\hline Null hypothesis & & & $\begin{array}{c}\text { Groups common intercept: } \\
\text { Welch } \mathrm{F}(7,36.0)=0.309 \\
p \text {-value }=0.944\end{array}$ & $\begin{array}{c}\text { Groups common intercept: } \\
\text { Welch } \mathrm{F}(7,32.5)=0.796 \\
p \text {-value }=0.680\end{array}$ & \\
\hline
\end{tabular}

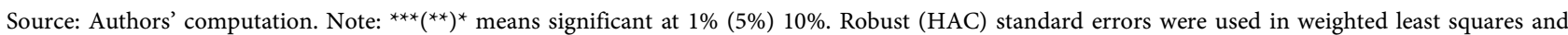
fixed effect estimations. 